\title{
International Standards for Fruit and Vegetables
}

CUCUMBERS

\section{Normes internationales pour les fruits et légumes CONCOMBRES}

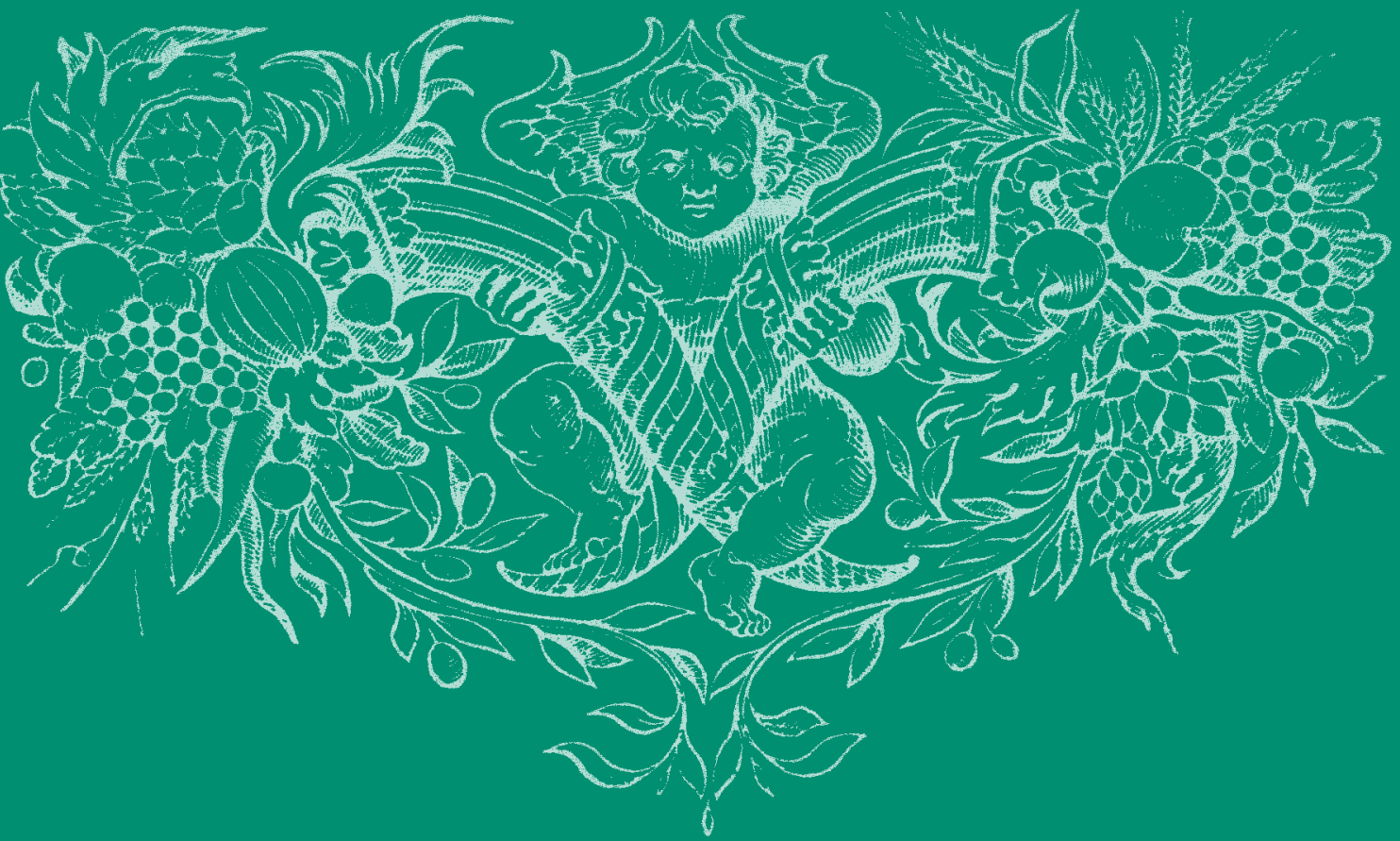



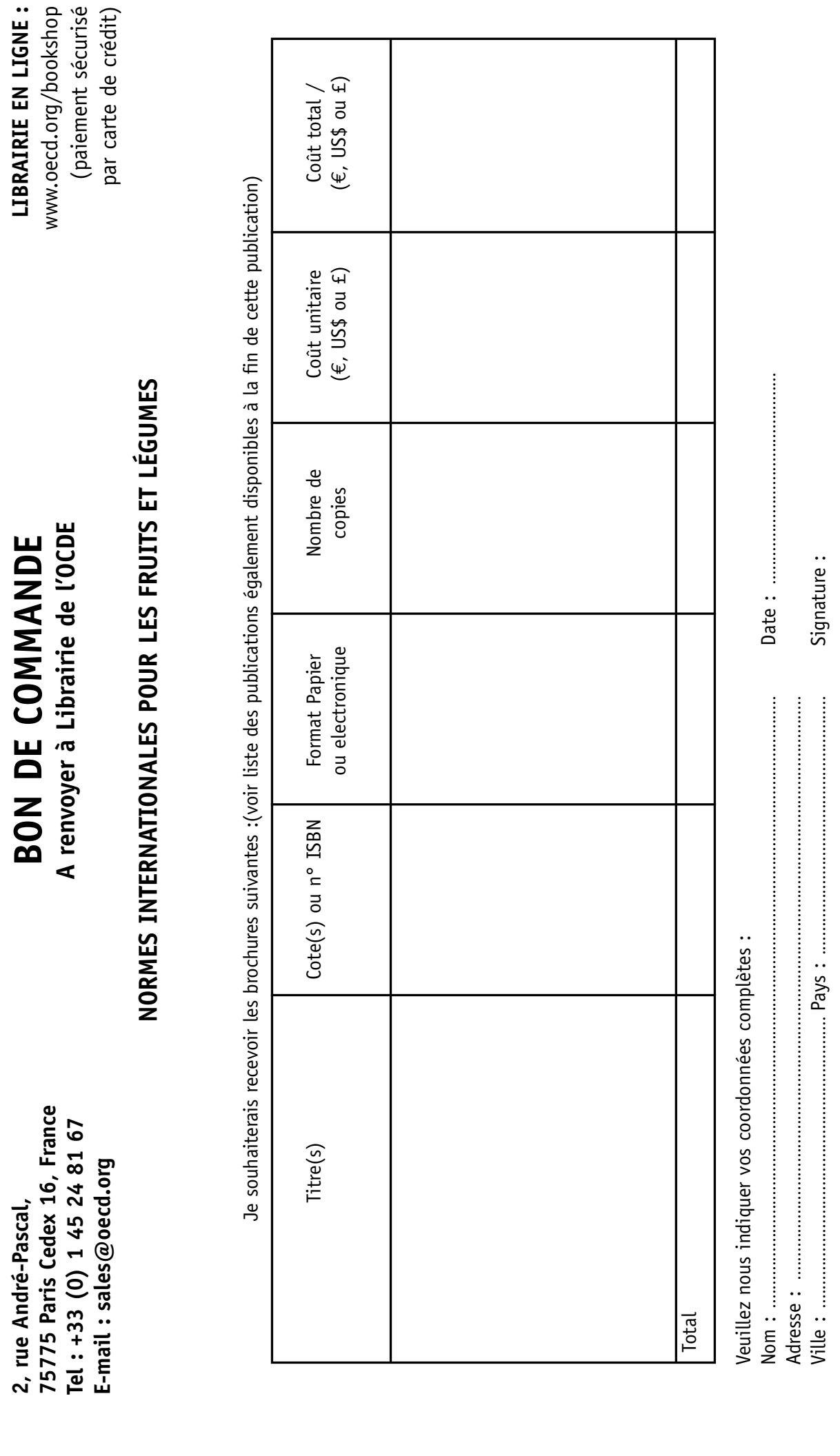

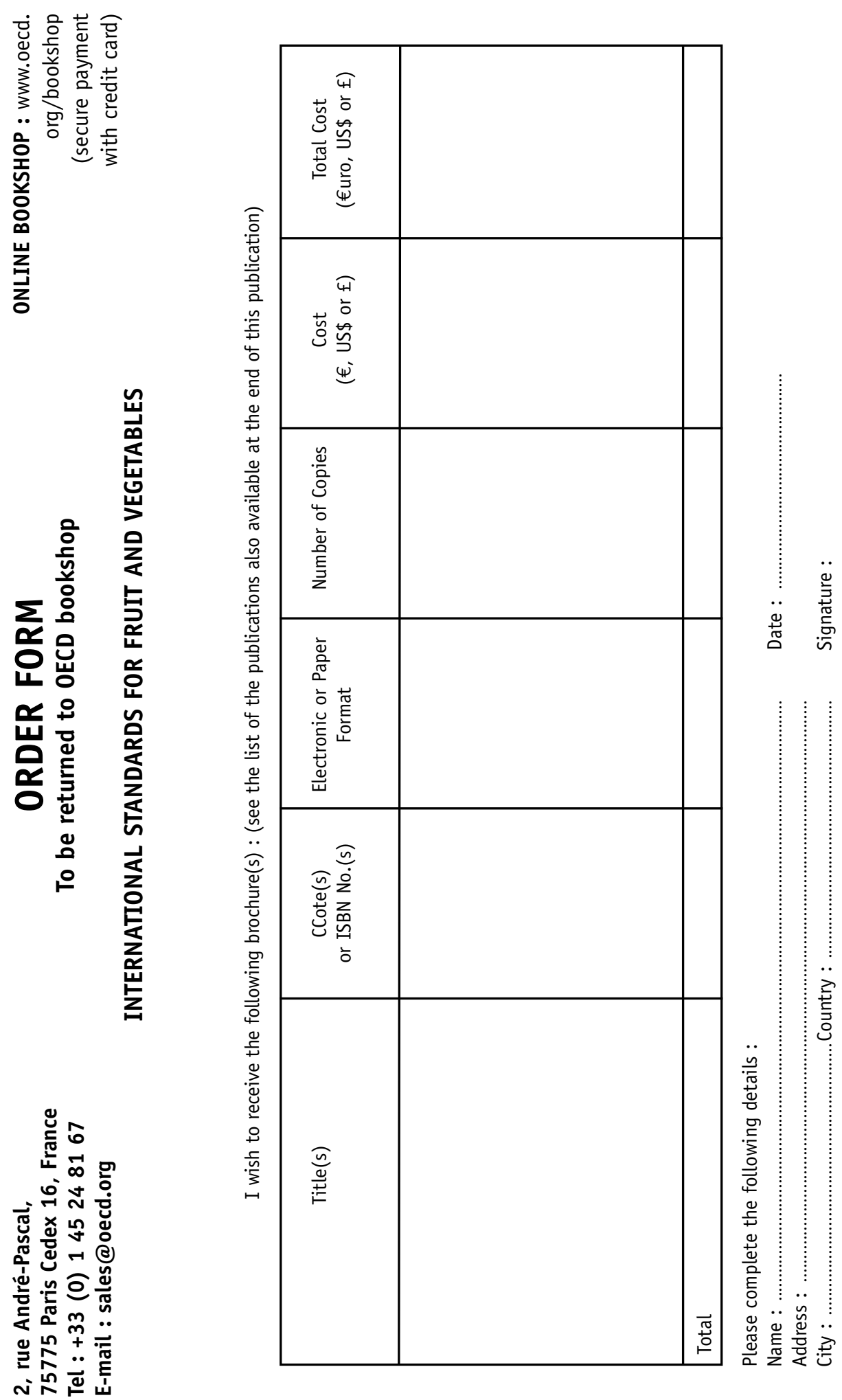


\section{INTERNATIONAL STANDARDS \\ FOR FRUIT AND VEGETABLES \\ NORMES INTERNATIONALES \\ POUR LES FRUITS ET LÉGUMES}

\section{Cucumbers}

\section{Concombres}




\section{ORGANISATION FOR ECONOMIC CO-OPERATION AND DEVELOPMENT}

The OECD is a unique forum where the governments of 30 democracies work together to address the economic, social and environmental challenges of globalisation. The OECD is also at the forefront of efforts to understand and to help governments respond to new developments and concerns, such as corporate governance, the information economy and the challenges of an ageing population. The Organisation provides a setting where governments can compare policy experiences, seek answers to common problems, identify good practice and work to co-ordinate domestic and international policies.

The OECD member countries are: Australia, Austria, Belgium, Canada, the Czech Republic, Denmark, Finland, France, Germany, Greece, Hungary, Iceland, Ireland, Italy, Japan, Korea, Luxembourg, Mexico, the Netherlands, New Zealand, Norway, Poland, Portugal, the Slovak Republic, Spain, Sweden, Switzerland, Turkey, the United Kingdom and the United States. The Commission of the European Communities takes part in the work of the OECD.

OECD Publishing disseminates widely the results of the Organisation's statistics gathering and research on economic, social and environmental issues, as well as the conventions, guidelines and standards agreed by its members.

This work is published on the responsibility of the Secretary-General of the OECD. The opinions expressed and arguments employed herein do not necessarily reflect the official views of the Organisation or of the governments of its member countries..

\section{OECD 2008}

No reproduction, copy, transmission or translation of this publication may be made without written permission. Applications should be sent to OECD Publishing: rights@oecd.org or by fax (33 1) 452413 91. Permission to photocopy a portion of this work should be addressed to the Centre français d'exploitation du droit de copie, 20, rue des Grands-Augustins, 75006 Paris, France (contact@cfcopies.com)..

\section{ORGANISATION DE COOPÉRATION ET DE DÉVELOPPEMENT ÉCONOMIQUES}

L'OCDE est un forum unique en son genre où les gouvernements de 30 démocraties œuvrent ensemble pour relever les défis économiques, sociaux et environnementaux, que pose la mondialisation. L'OCDE est aussi à l'avant-garde des efforts entrepris pour comprendre les évolutions de monde actuel et les préoccupations qu'elles font naître. Elle aide les gouvernements à faire face à des situations nouvelles en examinant des thèmes tels que le gouvernement d'entreprise, l'économie de l'information et les défis posés par le vieillissement de la population. L'Organisation offre aux gouvernements un cadre leur permettant de comparer leurs expériences en matière de politiques, de chercher des réponses à des problèmes communs, d'identifier les bonnes pratiques et de travailler à la coordination des politiques nationales et internationales

Les pays membres de l'OCDE sont: l'Allemagne, l'Australie, l'Autriche, la Belgique, le Canada, la Corée, le Danemark, l'Espagne, les États-Unis, la Finlande, la France, la Grèce, la Hongrie, l'Irlande, l'Islande, l'Italie, le Japon, le Luxembourg, le Mexique, la Norvège, la Nouvelle-Zélande, les Pays-Bas, la Pologne, le Portugal, la République slovaque, la République tchèque, le Royaume-Uni, la Suède, la Suisse et la Turquie. La Commission des Communautés européennes participe aux travaux de l'OCDE.

Les Éditions OCDE assurent une large diffusion aux travaux de l'Organisation. Ces derniers comprennent les résultats de l'activité de collecte de statistiques, les travaux de recherche menés sur des questions économiques, sociales et environnementales, ainsi que les conventions, les principes directeurs et les modèles développés par les pays membres.

Cet ouvrage est publié sous la responsabilité du Secrétaire général de l'OCDE. Les opinions et les interprétations exprimées ne reflètent pas nécessairement les vues de l'OCDE ou des gouvernements de ses pays membres.

\section{() OCDE 2008}

Toute reproduction, copie, transmission ou traduction de cette publication doit faire l'objet d'une autorisation écrite. Les demandes doivent être adressées aux Éditions OCDE rights@oecd.org ou par fax (33 1) 452413 91. Les demandes d'autorisation de photocopie partielle doivent être adressées directement au Centre français d'exploitation du droit de copie, 20, rue des Grands-Augustins, 75006 Paris, France (contact@cfcopies.com). 


\section{Foreword}

Within the framework of the activities of the Scheme for the Application of International Standards for Fruit and Vegetables* set up by OECD in 1962, explanatory brochures comprising comments and illustrations are published to facilitate the common interpretation of standards in force by both the Controlling Authorities and professional bodies responsible for the application of standards or interested in the international trade in these products.

The Scheme for the Application of International Standards for Fruit and Vegetables shall be open to States being Member countries of the United Nations Organization or its specialised agencies or the World Trade Organisation desiring to participate therein in accordance with the procedure for participation set out in the Decision C(2006)95 of the OECD Council dated 15 June 2006.

This brochure is published in English and French under the responsibility of the SecretaryGeneral of the OECD who declares it in line with the standard for "Cucumbers".**

\section{Avant-propos}

Dans le cadre des activités du Régime pour l'Application de Normes Internationales aux Fruits et Légumes* crée en 1962 par l'OCDE, des brochures sont publiées sous forme de commentaires et d'illustrations, en vue de faciliter l'interprétation commune des normes en vigueur, tant de la part des services de contrôle que des milieux professionnels responsables de l'application des normes ou intéressés aux échanges internationaux de ces produits.

Le Régime pour l'Application de Normes Internationales aux Fruits et Légumes est ouvert aux pays Membres de l'Organisation des Nations Unies ou de ses institutions spécialisées ou de l'Organisation Mondiale du Commerce, qui désirent y participer, conformément à la procédure de participation qui fait l'objet de la Décision du Conseil de l'OCDE C(2006)95 du 15 juin 2006.

Cette brochure est publiée en français et en anglais sous la responsabilité du Secrétaire général de l'OCDE qui la déclare en harmonie avec la norme "Concombres".**

* For more information on the Scheme, see http://www.oecd.org/agr/fv.

** Standard also recommended by the Economic Commission for Europe of the United Nations Organization under the reference FFV-15.

* Pour plus d'informations sur le Régime, voir consulter le site http://www.oecd.org/agr/fv.

** Norme également recommandée par la Commission Economique pour l'Europe de L'ONU sous la référence FFV-15. 


\section{TABLE OF CONTENTS}

\section{COMPARATIVE SUMMARY TABLE OF REQUIREMENTS}

II. PROVISIONS CONCERNING QUALITY 18

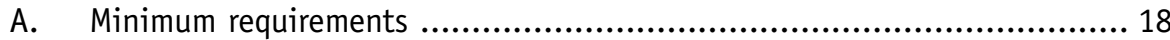

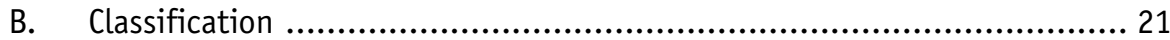

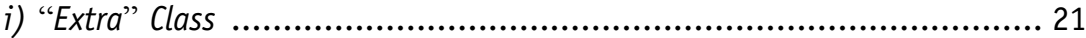

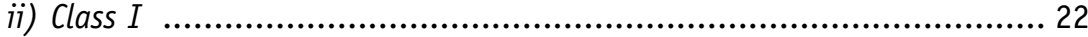

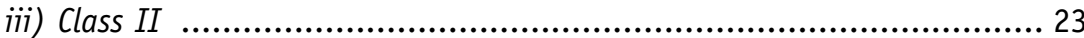

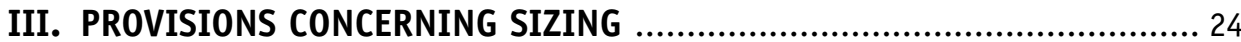

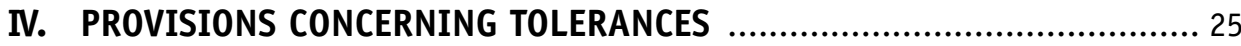

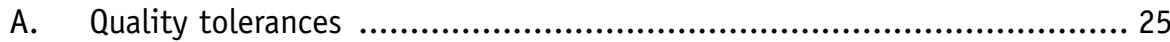

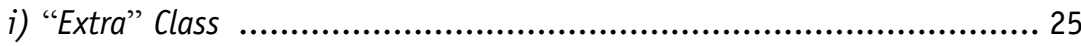

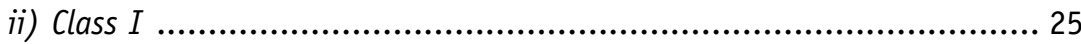

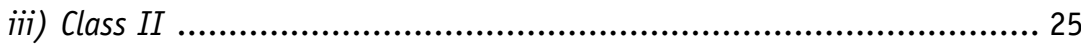

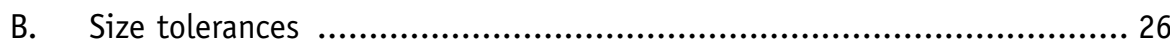

V. PROVISIONS CONCERNING PRESENTATION _...................................... 27

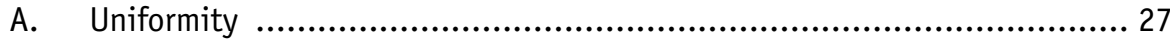

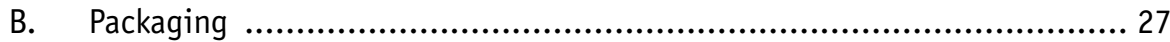

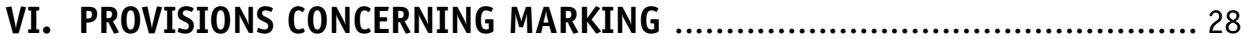

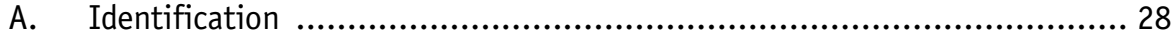

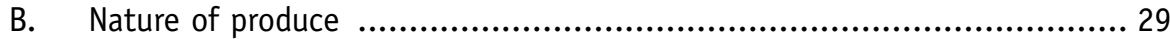

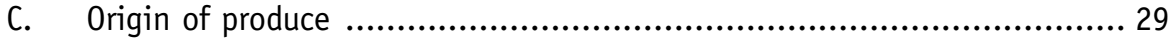

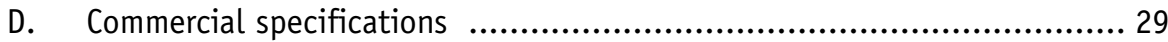

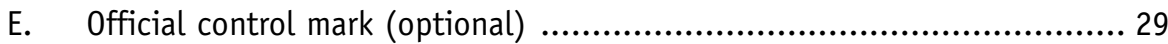

annex PHOTOS 


\section{TABLE DES MATIÈRES}

TABLEAU COMPARATIF RÉSUMÉ DES DISPOSITIONS DE LA NORME 32

I. DEFINITION DU PRODUIT 39

II. DISPOSITIONS CONCERNANT LA QUALITE 40

A. Caractéristiques minimales .............................................. 40

B. Classification ............................................................ 43

i) Catégorie "Extra" ....................................................... 43

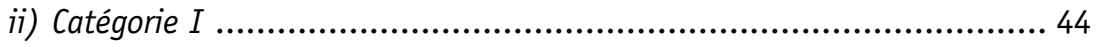

iii) Catégorie II ................................................................ 45

III. DISPOSITIONS CONCERNANT LE CALIBRAGE ................................... 46

IV. DISPOSITIONS CONCERNANT LES TOLERANCES ............................. 47

A. Tolérances de qualité ................................................... 47

i) Catégorie "Extra" ............................................................ 47

ii) Catégorie $I$................................................................... 47

iii) Catégorie II ............................................................... 47

B. Tolérances de calibre ..................................................... 48

V. DISPOSITIONS CONCERNANT LA PRESENTATION .............................. 49

A. Homogénéité ............................................................ 49

B. Conditionnement ................................................................ 49

VI. DISPOSITIONS CONCERNANT LE MARQUAGE ................................. 50

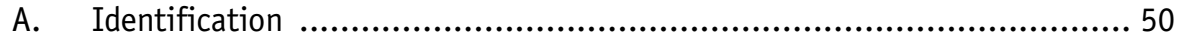

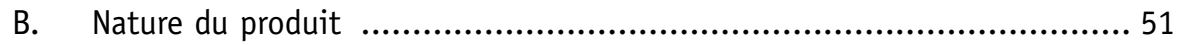

C. Origine du produit .......................................................... 51

D. Caractéristiques commerciales ............................................. 51

E. Marque officielle de contrôle (facultative) .................................. 51

annexe PHOTOS

(C) 0ECD 2008 
This publication is also available as an electronic book (PDF file).

Any necessary updates will first be included in the electronic book.

Cette publication est également disponible sous forme électronique (fichier PDF). Des amendements nécessaires seront publiés tout d'abord sous forme électronique. 


\section{Cucumbers}


COMPARATIVE SUMMARY TABLE OF REQUIREMENTS LAID DOWN BY THE STANDARD

\begin{tabular}{|c|c|c|c|}
\hline \multirow{2}{*}{ REQUIREMENTS } & \multicolumn{3}{|c|}{ CLASSES } \\
\hline & "Extra" & $\mathrm{I}$ & II \\
\hline Market value & Superior quality & Good quality & Marketable quality \\
\hline $\begin{array}{l}\text { I. Definition of produce } \\
\text { (all classes) }\end{array}$ & \multicolumn{3}{|c|}{ All varieties (cultivars) of Cucumis sativus $\mathrm{L}$. } \\
\hline $\begin{array}{l}\text { II. Provisions } \\
\text { concerning quality }\end{array}$ & \multicolumn{3}{|c|}{$\begin{array}{l}\text { However, if applied at stages following export, products } \\
\text { may show in relation to the requirements of the standard: } \\
\text { - a slight lack of freshness and turgidity, } \\
\text { - for products graded in classes other than the "Extra" } \\
\text { class, a slight deterioration due to their development } \\
\text { and their tendency to perish. } \\
\text { The holder/seller of the products may not display such } \\
\text { products or offer them for sale, or deliver or market them in } \\
\text { any manner other than in conformity with this standard. The } \\
\text { holder shall be responsible for observing such conformity. }\end{array}$} \\
\hline $\begin{array}{ll}\text { II.A. } & \text { Minimum } \\
\text { requirements } \\
\text { (all classes) }\end{array}$ & \multicolumn{3}{|c|}{$\begin{array}{l}\text { - intact } \\
\text { - sound } \\
\text { - clean, practically free of any visible foreign matter } \\
\text { - fresh in appearance and firm } \\
\text { - practically free from pests } \\
\text { - free from damage caused by pests affecting the flesh } \\
\text { - free of bitter taste } \\
\text { - free of: } \\
\text { - abnormal external moisture } \\
\text { - any foreign smell and/or taste } \\
\text { - sufficiently developed, but seeds must be soft } \\
\text { - the development and condition must be such as to } \\
\text { enable them to withstand transportation and handling } \\
\text { and to arrive in a satisfactory condition at the place } \\
\text { of destination }\end{array}$} \\
\hline
\end{tabular}




\section{COMPARATIVE SUMMARY TABLE OF REQUIREMENTS} LAID DOWN BY THE STANDARD

\begin{tabular}{|c|c|c|c|}
\hline \multirow{2}{*}{ REQUIREMENTS } & \multicolumn{3}{|c|}{ CLASSES } \\
\hline & "Extra" & I & II \\
\hline Market value & Superior quality & Good quality & Marketable quality \\
\hline $\begin{array}{l}\text { II.B. Quality } \\
\text { requirements }\end{array}$ & & & \\
\hline - Appearance & $\begin{array}{l}\text { characteristic of } \\
\text { the variety }\end{array}$ & $\begin{array}{l}\text { characteristic of } \\
\text { the variety }\end{array}$ & $\begin{array}{l}\text { in keeping } \\
\text { with minimum } \\
\text { requirements }\end{array}$ \\
\hline - Development & well developed & $\begin{array}{l}\text { reasonably } \\
\text { developed }\end{array}$ & $\begin{array}{l}\text { in keeping with } \\
\text { the minimum } \\
\text { requirements }\end{array}$ \\
\hline - Shape & $\begin{array}{l}\text { well shaped and } \\
\text { practically straight } \\
\text { (maximum height } \\
\text { of the inner arc: } \\
10 \mathrm{~mm} \text { per } 10 \mathrm{~cm} \\
\text { of length) } \\
\\
\text { a } \\
\text { caused by seed } \\
\text { development } \\
\text { a slight defect } \\
\text { excluding that } \\
\text { a but }\end{array}$ & $\begin{array}{l}\text { reasonably well } \\
\text { shaped and } \\
\text { practically straight } \\
\text { (maximum height } \\
\text { of the inner arc: } \\
10 \mathrm{~mm} \text { per } 10 \mathrm{~cm} \\
\text { of length) }\end{array}$ & $\begin{array}{l}\text { slightly crooked } \\
\text { cucumbers } \\
\text { (maximum height } \\
\text { of the inner arc: } \\
20 \mathrm{~mm} \text { per } 10 \mathrm{~cm} \\
\text { of length) } \\
\text { crooked cucumbers } \\
\text { having a height } \\
\text { of the inner arc } \\
\text { of more than } \\
20 \text { mm per } 10 \mathrm{~cm} \\
\text { of length are } \\
\text { allowed, provided } \\
\text { they have no more } \\
\text { than slight defects } \\
\text { in colouring and } \\
\text { have no defects or } \\
\text { deformation other } \\
\text { than crookedness, } \\
\text { and they are } \\
\text { separately packed } \\
\text { defects allowed, } \\
\text { but excluding } \\
\text { those by serious } \\
\text { seed development }\end{array}$ \\
\hline
\end{tabular}


COMPARATIVE SUMMARY TABLE OF REQUIREMENTS

LAID DOWN BY THE STANDARD

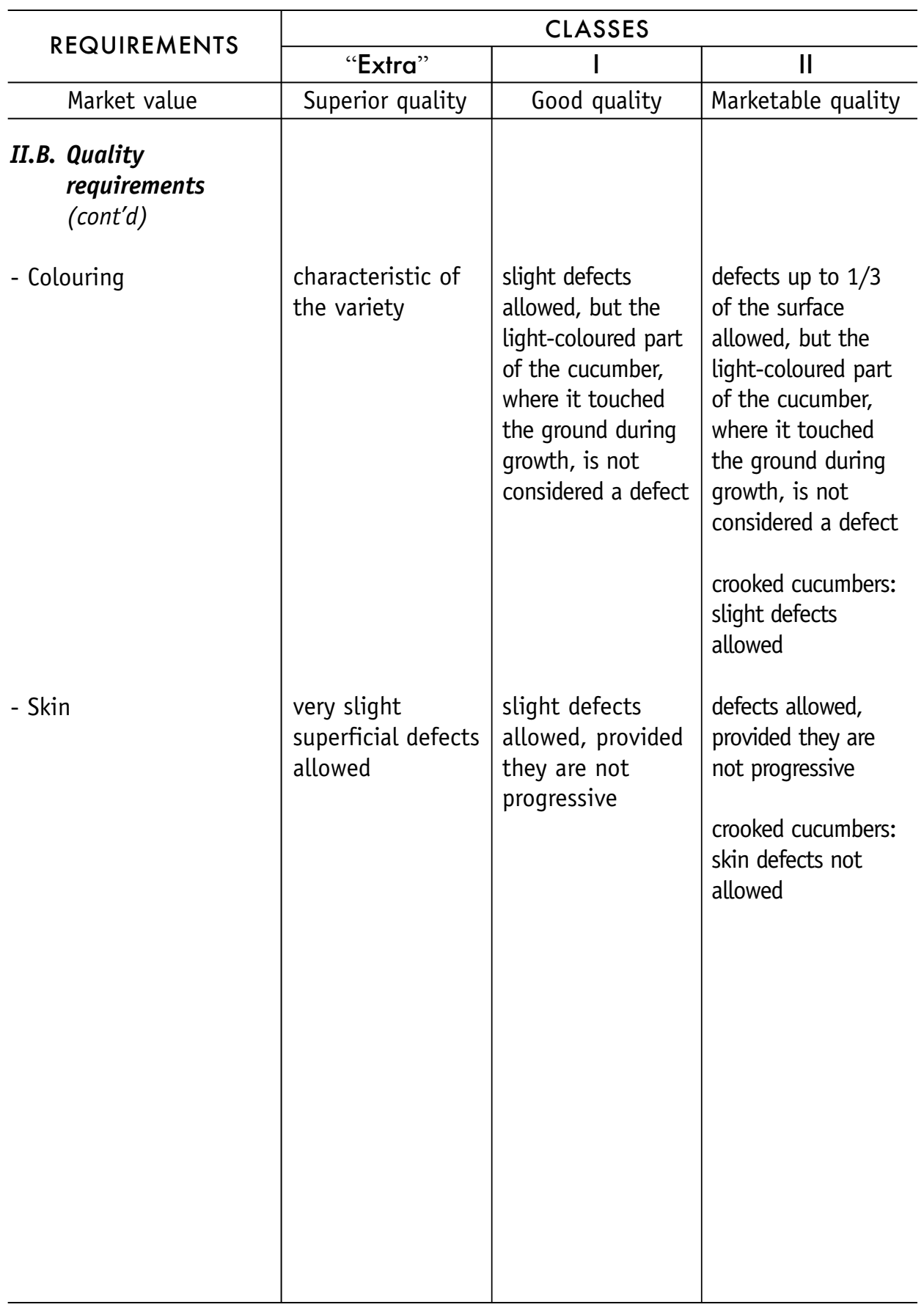




\section{COMPARATIVE SUMMARY TABLE OF REQUIREMENTS LAID DOWN BY THE STANDARD}

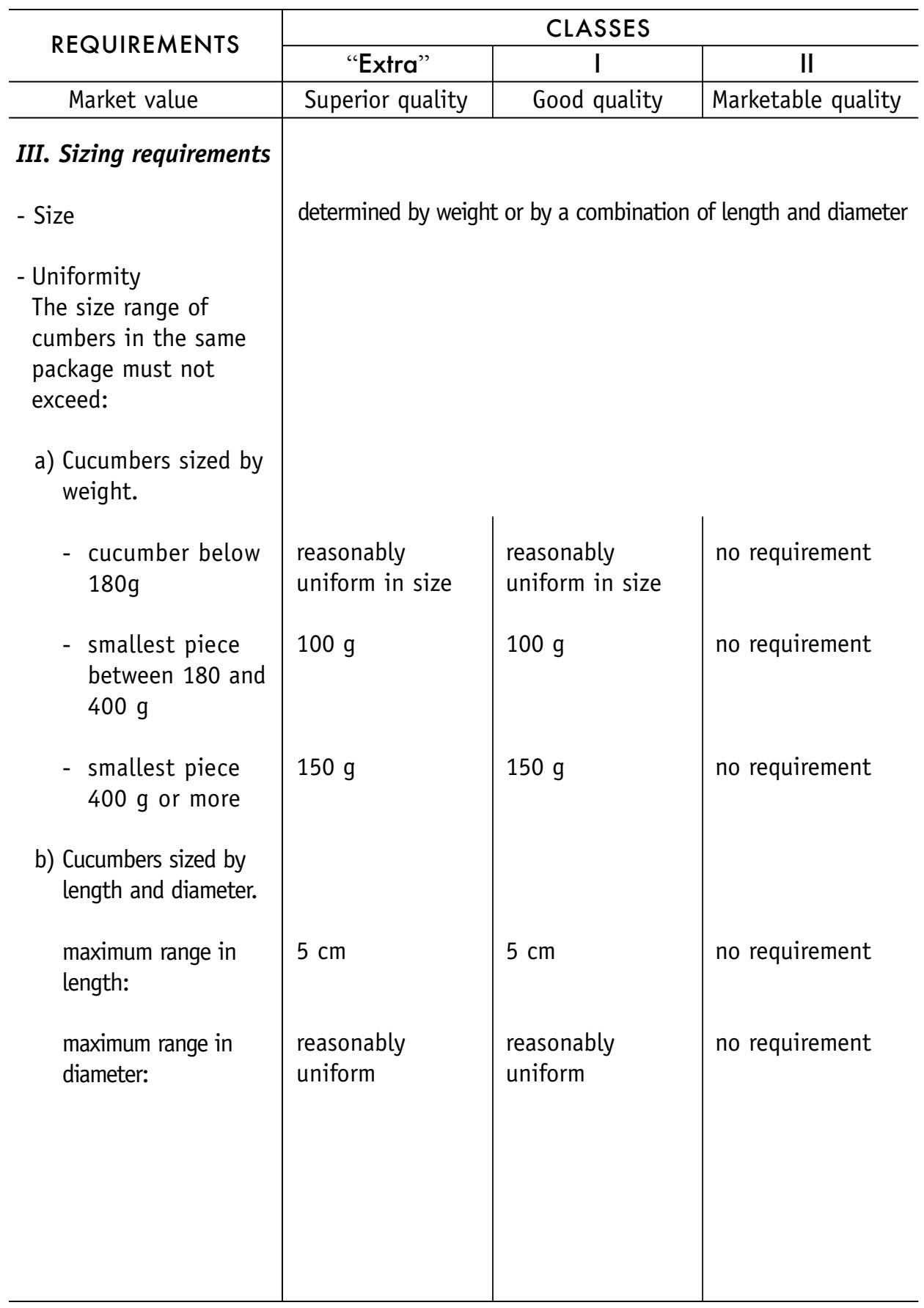


COMPARATIVE SUMMARY TABLE OF REQUIREMENTS

LAID DOWN BY THE STANDARD

\begin{tabular}{l|l|c|c}
\hline \multirow{2}{*}{ REQUIREMENTS } & \multicolumn{2}{|c}{ CLASSES } \\
\cline { 2 - 4 } & \multicolumn{1}{|c}{ "Extra" } & I & II \\
\hline \multicolumn{1}{c|}{ Market value } & Superior quality & Good quality & Marketable quality \\
\hline $\begin{array}{l}\text { IV. } \begin{array}{l}\text { Tolerances } \\
\text { (by number) }\end{array} \\
\text { - Quality }\end{array}$ & $5 \%$ & $10 \%$ & $10 \%$ \\
$\begin{array}{l}\text { of which cucumbers } \\
\text { having tips with a } \\
\text { bitter taste }\end{array}$ & -- & -- & $2 \%$ \\
- Size & $10 \%$ & $10 \%$ & $10 \%$
\end{tabular}

However, this tolerance is applicable only to produce which differs by no more than 10 per cent from the size and weight limits specified. 


\section{COMPARATIVE SUMMARY TABLE OF REQUIREMENTS LAID DOWN BY THE STANDARD}

\begin{tabular}{|c|c|c|c|}
\hline \multirow{2}{*}{ REQUIREMENTS } & \multicolumn{3}{|c|}{ CLASSES } \\
\hline & "Extra" & I & II \\
\hline Market value & Superior quality & Good quality & Marketable quality \\
\hline \multicolumn{4}{|l|}{$\begin{array}{l}\text { V. Presentation } \\
\text { (all classes) }\end{array}$} \\
\hline - Uniformity & \multicolumn{3}{|c|}{$\begin{array}{l}\text { - origin } \\
\text { - variety or commercial type } \\
\text { - quality } \\
\text { - size (if sized) } \\
\text { - visible part of the package must be representative of } \\
\text { the entire content }\end{array}$} \\
\hline - Packaging & \multicolumn{3}{|c|}{$\begin{array}{l}\text { - protects produce properly } \\
\text { - cucumbers must be sufficiently tightly packed as to } \\
\text { avoid damage during transport } \\
\text { - materials inside the package clean and of a quality to } \\
\text { avoid causing external or internal damage } \\
\text { - non toxic ink or glue on printing or labelling } \\
\text { - free of all foreign matter } \\
\text { - stickers individually affixed to the produce shall be such } \\
\text { that, when removed, they neither leave visible traces of } \\
\text { glue, nor lead to skin defects } \\
\text { - crooked cucumbers must be packed separately }\end{array}$} \\
\hline $\begin{array}{l}\text { VI. } \text { Marking } \\
\text { (all classes) }\end{array}$ & \multicolumn{3}{|c|}{$\begin{array}{l}\text { - identification of packer and/or dispatcher } \\
\text { - "cucumbers" if contents are not visible from outside } \\
\text { - "crooked cucumbers", where appropriate } \\
\text { - country of origin (region optional) } \\
\text { - quality class } \\
\text { - size (if sized) expressed in minimum and maximum weight } \\
\text { - number of units (optional) } \\
\text { - official control mark (optional) }\end{array}$} \\
\hline
\end{tabular}


On the following pages, the official text of the standard is indicated in blue bold, the interpretative text of the standard is indicated in black. 


\section{DEFINITION OF PRODUCE}

This standard applies to cucumbers of varieties (cultivars) grown from Cucumis sativus L., to be supplied fresh to the consumer, cucumbers for processing and gherkins being excluded.

The varieties of cucumber vary in shape, size and skin. $\Rightarrow$ photos 1 to 2

While cucumbers for processing do not have to follow a special definition, the gherkins are obtained from varietal types producing of a size making at least 85 units per kilogram. $\Rightarrow$ photo 3 


\section{PROVISIONS CONCERNING QUALITY}

The purpose of the standard is to define the quality requirements for cucumbers at the export control stage, after preparation and packaging.

However, if applied at stages following export, products may show in relation to the requirements of the standard:

\section{- a slight lack of freshness and turgidity}

- for products graded in classes other than the "Extra" Class, a slight deterioration due to their development and their tendency to perish.

The holder/seller of the products may not display such products or offer them for sale, or deliver or market them in any manner other than in conformity with this standard. The holder shall be responsible for observing such conformity.

\section{A. Minimum requirements}

In all classes, subject to the special provisions for each class and the tolerances allowed, the cucumbers must be:

\section{- intact.}

Cucumbers must not have any mutilation or injury spoiling the integrity of the produce. $\Rightarrow$ photos 4 to 5

- sound; produce affected by rotting or deterioration such as to make it unfit for consumption is excluded.

Cucumbers must be free from disease or serious deterioration, which appreciably affects their appearance, edibility or market value. In particular, this excludes cucumbers affected by rotting, even if the signs are very slight but liable to make the cucumbers unfit for consumption upon arrival at their destination.

Cucumbers showing the following defects are therefore excluded:

a) severe bruises. $\Rightarrow$ photo 6

b) diseases. $\Rightarrow$ photos 7 to 12

c) damages caused by low temperature or frost. $\Rightarrow$ photos 13

d) physiological defects such as severe hollowness due to waterstress affecting the texture of the flesh and the eating quality. 
- clean, practically free of any visible foreign matter.

Cucumbers must be practically free of visible soil, dust, chemical residue or other visible foreign matter. $\Rightarrow$ photos 14 to 16

- fresh in appearance, and firm.

Cucumbers showing a lack of freshness show yellow discoloration and are to be excluded. $\Rightarrow$ photo 17

Cucumbers must be firm and turgid. Cucumbers that have lost their firmness and show a "weak neck" and/or show any sign of shrivelling or dehydration are to be excluded. $\Rightarrow$ photo 18

- practically free from pests.

Cucumbers must be practically free of insects or other pests. The presence of pests can detract from the commercial presentation and acceptance of the cucumbers.

- free from damage caused by pests affecting the flesh.

Pest damage can detract from the general appearance, keeping quality and edibility of the cucumbers. $\Rightarrow$ photo 19

- free of bitter taste (subject to the special provision for Class II under the heading "IV. PROVISIONS CONCERNING TOLERANCES").

Bitterness in cucumbers - related to cucurbitacins - is influenced by both genetic and environmental factors.

- free of abnormal external moisture.

This provision applies to excessive moisture, for example, free water lying inside the package but does not include condensation on produce following release from cool storage or refrigerated vehicle.

- free of any foreign smell and/or taste.

This refers particularly to cucumbers which have been stored on badly kept premises or have travelled in a badly maintained vehicle, especially cucumbers which have acquired a strong smell from other produce stored on the same premises or travelling in the same vehicle. Therefore, care should be taken to use only non-smelling materials as protection in packaging. 
Cucumbers must be sufficiently developed but their seeds must be soft.

Cucumbers that are not sufficiently developed are pointed and wrinkled at the flower end. $\Rightarrow$ photo 20

Cucumbers with developing seeds may externally show deformation. Development of hard seeds has to be checked by cutting the cucumbers. $\Rightarrow$ photo 21

The development and condition of the cucumbers must be such as to enable them:

- to withstand transportation and handling, and

- to arrive in satisfactory condition at the place of destination. 


\section{B. Classification}

Cucumbers are classified in three classes, as defined below:

i) "Extra” Class

Cucumbers in this class must be of superior quality. They must have all the typical characteristics and colouring of the variety and/or commercial type.

Cucumbers must be very carefully presented. $\Rightarrow$ photos 22 and 40

They must be:

- well developed.

- well shaped and practically straight

(maximum height of the inner arc: $10 \mathrm{~mm}$ per $10 \mathrm{~cm}$ of length of the cucumber). $\Rightarrow$ photo 23

For all classes, the crookedness of the cucumber is determined by measuring the length of the cucumber and the height of the inner arc. The length of the cucumber is measured by taking the shortest distance between the flower-scar and the implant of the stalk. The height of the inner arc is the length of the largest distance between the line from flower-scar to stalk-implant and the inner arc of the cucumber. $\Rightarrow$ photo 24

They must be free from defects, including all deformations and particularly those caused by seed formation, with the exception of very slight superficial defects, provided these do not affect the general appearance of the produce, the quality, the keeping quality and presentation in the package.

Very slight superficial defects may appear during cultivation, harvest, storage, packaging or transportation. $\Rightarrow$ photo 25 


\section{ii) Class I}

Cucumbers in this class must be of good quality. They must be characteristic of the variety and/or commercial type.

Although the Class I quality requirements are less strict than for "Extra" Class, Class I cucumbers must, nevertheless, be carefully selected and presented. $\Rightarrow$ photo 25 and 41

They must be:

- reasonably developed.

- reasonably well-shaped and practically straight (maximum height of the inner arc: $10 \mathrm{~mm}$ per $10 \mathrm{~cm}$ of length of the cucumber). $\Rightarrow$ photos 23 to 24

The following slight defects, however, may be allowed provided these do not affect the general appearance of the produce, the quality, the keeping quality and presentation in the package:

- a slight defect in shape, but excluding that caused by seed development. $\Rightarrow$ photos 27 to 28

- slight defects in colouring, but the light-coloured part of the cucumber, where it touched the ground during growth, is not considered a defect.

Slight defects in colouring may occur where a leaf covering parts of the cucumber. $\Rightarrow$ photo 29

- slight skin defects, provided they are not progressive.

light skin defects due to rubbing, thrips damage, or healed cracks are allowed. Growth cracks may be linked to shape defects and appear mainly on the inner curve of the cucumbers as the outer curve is growing faster than the inner curve. $\Rightarrow$ photos 30 to 32 


\section{iii) Class II}

This class includes cucumbers that do not qualify for inclusion in the higher classes but satisfy the minimum requirements specified above.

Cucumbers in this class must be of marketable quality, suitably presented and suitable for human consumption. $\Rightarrow$ photo 42

The following defects may be allowed, provided the cucumbers retain their essential characteristics as regards the quality, the keeping quality and presentation:

- defects in shape, but excluding those by serious seed development; slightly crooked cucumbers having a maximum height of the inner arc of $20 \mathrm{~mm}$ per $10 \mathrm{~cm}$ of length are allowed. $\Rightarrow$ photos 23 to 24 and photo 33

- defects in colouring up to one-third of the surface, but the light-coloured part of the cucumber, where it touched the ground during growth, is not considered a defect. $\Rightarrow$ photo 34

- $\quad$ skin defects, provided they are not progressive. $\Rightarrow$ photos 35 to 37

Crooked cucumbers having a height of the inner arc of more than $20 \mathrm{~mm}$ per $10 \mathrm{~cm}$ of length are allowed, provided they have no more than slight defects in colouring and have no defects or deformation other than crookedness, and they are separately packed. $\Rightarrow$ photos 38 to 39

In the packages containing those crooked cucumbers, cucumbers showing severe shape defects are considered to be crooked cucumbers too. 


\section{PROVISIONS CONCERNING SIZING}

Size is determined by either weight or by a combination of length and diameter.

Uniformity in size is compulsory for Classes "Extra" and I.

To ensure uniformity, one of the following two options should be applied:

(a) Cucumbers sized by weight

The range in weight of cucumbers in the same package must not exceed:

- cucumbers below $180 \mathrm{~g}$ should be reasonably uniform in size

- $100 \mathrm{~g}$ where the smallest piece weighs between 180 and $400 \mathrm{~g}$

- $150 \mathrm{~g}$ where the smallest piece weighs $400 \mathrm{~g}$ or more

(b) Cucumbers sized by length and diameter.

The range in length of cucumbers in the same package must not exceed:

- $5 \mathrm{~cm}$ in length between the longest and the shortest cucumber in the same package, and cucumbers should be reasonably uniform in diameter. 


\section{PROVISIONS CONCERNING TOLERANCES}

Tolerances in respect of quality and size shall be allowed in each lot for produce not satisfying the requirements of the class indicated.

Tolerances are provided to allow for human error during the grading and packing process. During grading and sizing it is not permitted to deliberately include out of grade produce, i.e. to exploit the tolerances deliberately.

The tolerances are determined after examining each sample and taking the average of all samples examined. The tolerances are stated in terms of percentage, by number of cucumbers in the total sample not conforming to the class or to the size indicated on the package.

\section{A. Quality Tolerances}

i) "Extra” Class

A total tolerance of 5 per cent, by number, of cucumbers not satisfying the requirements of the class but meeting those of Class I is allowed. Within this tolerance not more than 0.5 per cent in total may consist of produce satisfying the requirements of Class II quality.

\section{ii) Class I}

A total tolerance of 10 per cent, by number, of cucumbers not satisfying the requirements of the class but meeting those of Class II is allowed. Within this tolerance not more than 1 per cent in total may consist of produce satisfying neither the requirements of Class II quality nor the minimum requirements. Produce affected by rotting or any other deterioration rendering it unfit for consumption is excluded.

\section{iii) Class II}

A total tolerance of 10 per cent, by number, of cucumbers satisfying neither the requirements of the class nor the minimum requirements is allowed. Produce affected by rotting or any other deterioration rendering it unfit for consumption is excluded. Within this tolerance, a maximum of 2 per cent by number of fruit may have tips with a bitter taste.

Within the tolerance of Class II, cucumbers showing "weak necks" that do not reach beyond the shoulders are allowed. 


\section{B. Size Tolerances}

For all classes (if sized): A total tolerance of 10 per cent, by number, of cucumbers not satisfying the requirements as regards sizing is allowed. However, this tolerance is applicable only to produce that differs by no more than 10 per cent from the size and weight limits specified.

Deviation from the size range: $10 \%$ by number of cucumbers may be allowed up to $10 \%$ above or below the indicated size range. 


\section{PROVISIONS CONCERNING PRESENTATION}

\section{A. Uniformity}

The contents of each package must be uniform and contain only cucumbers of the same origin, variety or commercial type, quality and size (if sized). $\Rightarrow$ photos 40 to 42

The visible part of the contents of the package must be representative of the entire contents.

A special effort should be made to suppress camouflage, i.e. concealing in the lower layers of the package produce inferior in quality and size to that displayed and marked.

Similarly prohibited is any packaging method or practice intended to give a deceptively superior appearance to the top layer of the consignment.

\section{B. Packaging}

The cucumbers must be packed in such a way as to protect the produce properly.

The cucumbers must be packed sufficiently tightly so as to avoid damage during transportation.

Packages must be of a quality, strength and characteristics to protect the produce during transportation and handling.

For protection purposes, especially against loss of humidity due to transpiration and a certain protection against low temperature, cucumbers may be wrapped in plastic film. $\Rightarrow$ photo 43

The materials used inside the package must be clean and of a quality such as to avoid causing any external or internal damage to the produce. The use of materials, particularly of paper or stamps bearing trade specifications, is allowed, provided the printing or labelling has been done with non-toxic ink or glue.

This provision is designed to ensure suitable protection of the produce by means of materials inside the package which are clean and also to prevent foreign matter such as leaves, sand or soil from spoiling its good presentation.

Stickers individually affixed to the produce shall be such that, when removed, they neither leave visible traces of glue, nor lead to skin defects.

Packages must be free of all foreign matter.

A visible lack of cleanliness in several packages could result in the goods being rejected.

$\bar{C}$ OECD 2008 


\section{PROVISIONS CONCERNING MARKING}

Each package ${ }^{1}$ must bear the following particulars in letters grouped on the same side, legibly and indelibly marked, and visible from the outside:

In the case of packed produce, all particulars must be grouped on the same side of the package, either on a label attached to or printed on the package with water-insoluble ink. $\Rightarrow$ photos 44 to 45

In the case of re-used packages, all previous labels must be carefully removed and previous indications deleted.

\section{A. Identification}

\section{Packer $\quad$ Name and physical address (e.g. street/city/region/postal code and/or $\}$ and, if different from the country of origin, the country) Dispatcher $\int$ or a code mark officially recognized by the national authority. ${ }^{2}$}

For inspection purposes, the "packer" is the person or firm responsible for the packaging of the produce (this does not mean the staff who actually carry out the work, who are responsible only to their employer). The code mark is not a trademark, but an official control system enabling the person or firm responsible for packaging to be readily identified. The dispatcher (shipper or exporter) may, however, voluntarily or compulsorily, assume sole responsibility for inspection purposes, in which case identification of the "packer" as defined above is no longer necessary.

To prevent indistinctness in the case where a code mark is used, the reference "packer", "dispatcher" and/or "exporter" (or equivalent abbreviations, i.e. "pack.", "exp.") has to be indicated in close connection with the code mark .

1. Package units of produce pre-packed for direct sale to the consumer shall not be subject to these marking provisions but shall conform to the national requirements. However, the markings referred to shall in any event be shown on the transport packaging containing such package units.

2. The national legislation of a number of countries requires the explicit declaration of the name and address. However, in the case where a code mark is used, the reference "packer and/or dispatcher (or equivalent abbreviations)" has to be indicated in close connection with the code mark, and the code mark should be preceded by the ISO 3166 (alpha) country/area code of the recognizing country, if not the country of origin. 


\section{B. Nature of produce}

- "Cucumbers" if the contents are not visible from the outside.

The name of the produce need only be stated on closed packages, whose contents are not visible from the outside.

- "Crooked cucumbers", where appropriate.

C. Origin of produce

- Country of origin and, optionally, district where grown, or national, regional or local place name.

Marking must include the country of origin, i. e. the country in which the cucumbers were grown (e.g. "Netherlands", "Spain"). Optionally, district of origin in national, regional or local terms may also be shown.

D. Commercial specifications

- Class.

Stating the class is compulsory.

- Size (if sized), expressed in minimum and maximum weight.

The size range must be stated for Classes "Extra" and I and may be stated for Class II, provided the cucumbers in Class II are sized.

- Number of fruits (optional).

E. Official control mark (optional) 


\section{Concombres}


TABLEAU COMPARATIF RESUME DES DISPOSITIONS DE LA NORME

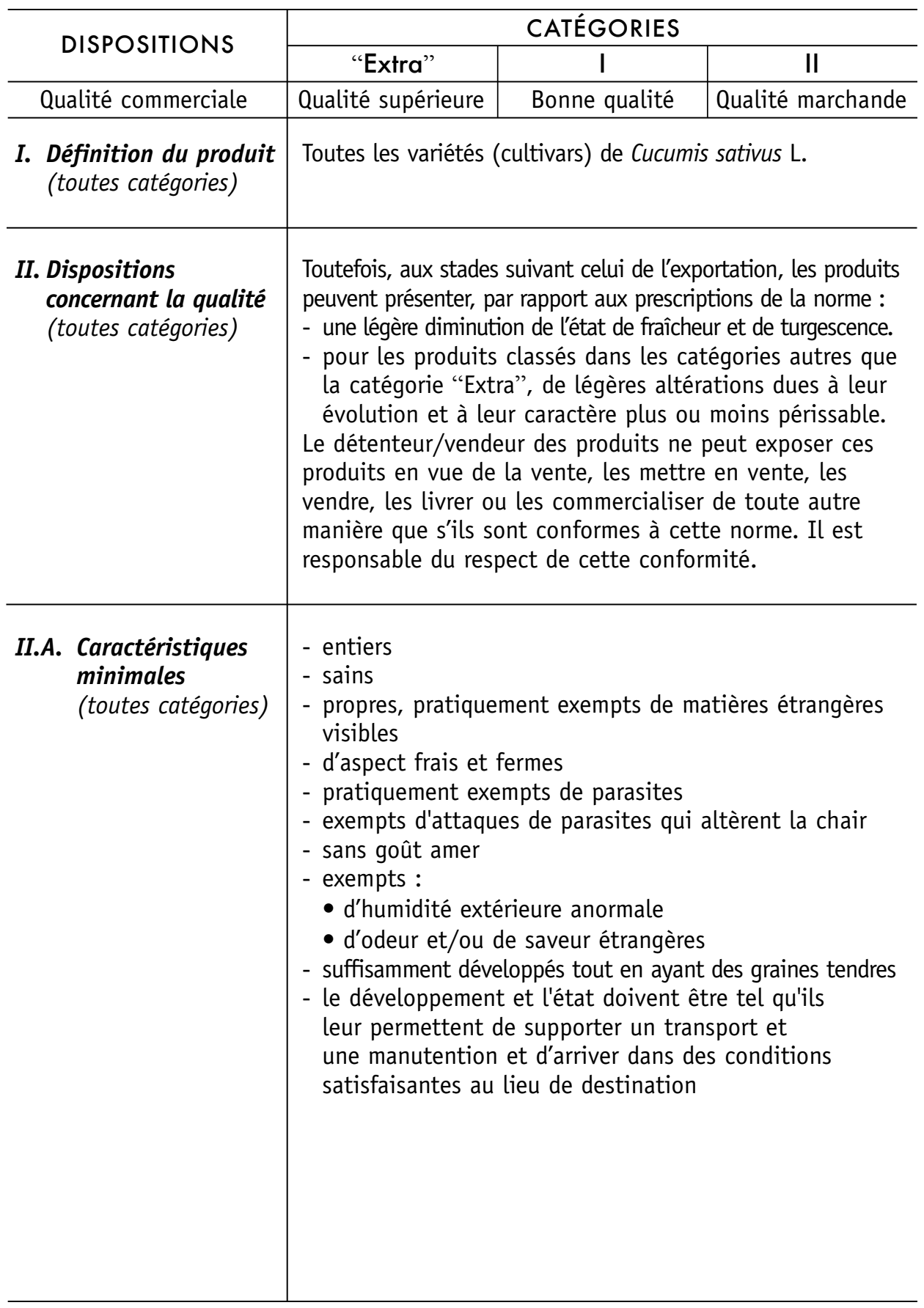


TABLEAU COMPARATIF RESUME DES DISPOSITIONS DE LA NORME

\begin{tabular}{|c|c|c|c|}
\hline \multirow{2}{*}{ DISPOSITIONS } & \multicolumn{3}{|c|}{ CATÉGORIES } \\
\hline & "Extra" & 1 & II \\
\hline Qualité commerciale & Qualité supérieure & Bonne qualité & Qualité marchande \\
\hline $\begin{array}{l}\text { II.B. Caractéristiques } \\
\text { qualitatives }\end{array}$ & & & \\
\hline - Aspect & $\begin{array}{l}\text { caractéristique de } \\
\text { la variété }\end{array}$ & $\begin{array}{l}\text { caractéristique de } \\
\text { la variété }\end{array}$ & $\begin{array}{l}\text { conforme aux } \\
\text { caractéristiques } \\
\text { minimales }\end{array}$ \\
\hline - Développement & bien développés & $\begin{array}{l}\text { suffisamment } \\
\text { développés }\end{array}$ & $\begin{array}{l}\text { conforme aux } \\
\text { caractéristiques } \\
\text { minimales }\end{array}$ \\
\hline - Forme & $\begin{array}{l}\text { bien formés et } \\
\text { pratiquement droits } \\
\text { (hauteur maximale } \\
\text { de l'arc intérieur : } \\
10 \mathrm{~mm} \text { pour } 10 \mathrm{~cm} \\
\text { de longueur) }\end{array}$ & $\begin{array}{l}\text { assez bien formés et } \\
\text { pratiquement droits } \\
\text { (hauteur maximale } \\
\text { de l'arc intérieur : } \\
10 \mathrm{~mm} \text { pour } 10 \mathrm{~cm} \\
\text { de longueur) } \\
\\
\\
\text { un léger défaut } \\
\text { admis, sauf } \\
\text { s'il est dû au } \\
\text { développement } \\
\text { des graines }\end{array}$ & $\begin{array}{l}\text { légèrement } \\
\text { recourbé } \\
\text { (hauteur maximale } \\
\text { de l'arc intérieur : } \\
20 \mathrm{~mm} \text { pour } 10 \mathrm{~cm} \\
\text { de longueur) } \\
\text { concombres } \\
\text { recourbés dont l'arc } \\
\text { intérieur présente } \\
\text { une hauteur } \\
\text { supérieure à } 20 \\
\text { mm pour } 10 \mathrm{~cm} \\
\text { de longueur du } \\
\text { concombre sont } \\
\text { admis à condition } \\
\text { qu'ils ne présentent } \\
\text { que de légers défauts } \\
\text { de coloration, à } \\
\text { l'exclusion de tout } \\
\text { autre défaut et de } \\
\text { toute déformation } \\
\text { autre que la } \\
\text { courbure, et qu'ils } \\
\text { soient conditionnés } \\
\text { à part } \\
\text { défauts autres } \\
\text { que ceux dus à un } \\
\text { développement } \\
\text { avancé de graines } \\
\text { admis }\end{array}$ \\
\hline
\end{tabular}


TABLEAU COMPARATIF RESUME DES DISPOSITIONS DE LA NORME

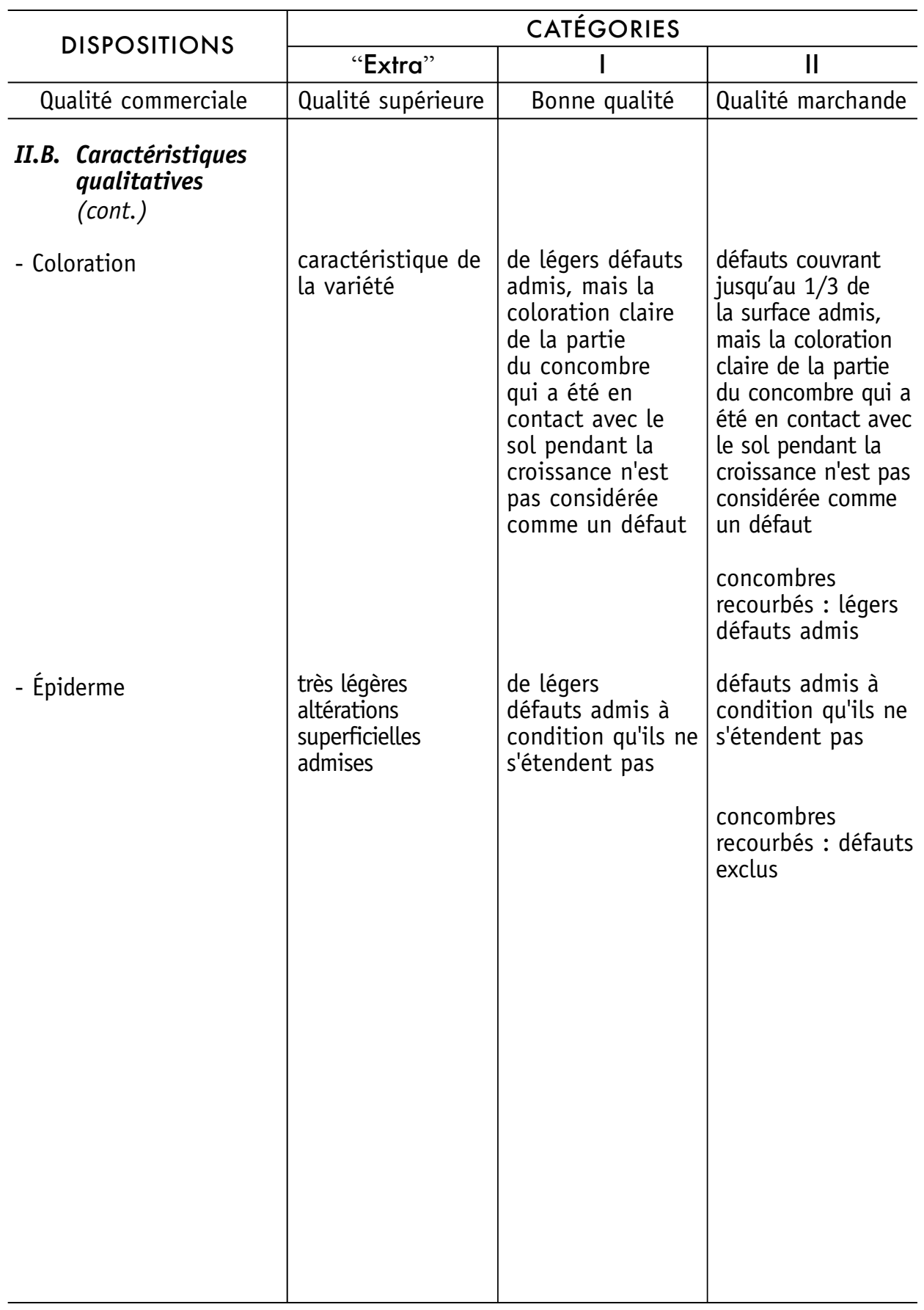


TABLEAU COMPARATIF RESUME DES DISPOSITIONS DE LA NORME

\begin{tabular}{|c|c|c|c|}
\hline \multirow{2}{*}{ DISPOSITIONS } & \multicolumn{3}{|c|}{ CATÉGORIES } \\
\hline & "Extra" & 1 & II \\
\hline Qualité commerciale & Qualité supérieure & Bonne qualité & Qualité marchande \\
\hline III. Calibrage & & & \\
\hline - Calibre & \multicolumn{3}{|c|}{$\begin{array}{l}\text { déterminé par le poids ou par une combinaison de la } \\
\text { longueur et du diamètre }\end{array}$} \\
\hline $\begin{array}{l}\text { - Homogénéité } \\
\text { L'écart de tailles des } \\
\text { concombres d'un même } \\
\text { emballage ne doit pas } \\
\text { excéder: }\end{array}$ & & & \\
\hline \multicolumn{4}{|l|}{$\begin{array}{l}\text { a) Concombres calibrés } \\
\text { par le poids }\end{array}$} \\
\hline $\begin{array}{l}\text { - concombres de } \\
\text { moins de } 180 \mathrm{~g}\end{array}$ & $\begin{array}{l}\text { calibre } \\
\text { raisonnablement } \\
\text { uniforme }\end{array}$ & $\begin{array}{l}\text { calibre } \\
\text { raisonnablement } \\
\text { uniforme }\end{array}$ & $\begin{array}{l}\text { calibre } \\
\text { raisonnablement } \\
\text { uniforme }\end{array}$ \\
\hline $\begin{array}{l}\text { - pièce de plus } \\
\text { petit calibre entre } \\
180 \text { et } 400 \mathrm{~g}\end{array}$ & $100 \mathrm{~g}$ & $100 \mathrm{~g}$ & aucune exigence \\
\hline $\begin{array}{l}\text { - pièce de plus } \\
\text { petit calibre au } \\
\text { moins } 400 \mathrm{~g}\end{array}$ & $150 \mathrm{~g}$ & $150 \mathrm{~g}$ & aucune exigence \\
\hline $\begin{array}{l}\text { b) Concombres calibrés } \\
\text { par la longueur et le } \\
\text { diamètre }\end{array}$ & & & aucune exigence \\
\hline $\begin{array}{l}\text { écart maximum de } \\
\text { logueur }\end{array}$ & $5 \mathrm{~cm}$ & $5 \mathrm{~cm}$ & aucune exigence \\
\hline $\begin{array}{l}\text { écart maximum de } \\
\text { diamètre }\end{array}$ & $\begin{array}{l}\text { raisonnablement } \\
\text { uniforme }\end{array}$ & $\begin{array}{l}\text { raisonnablement } \\
\text { uniforme }\end{array}$ & aucune exigence \\
\hline
\end{tabular}


TABLEAU COMPARATIF RESUME DES DISPOSITIONS DE LA NORME

\begin{tabular}{l|c|c|c}
\hline \multirow{2}{*}{ DISPOSITIONS } & \multicolumn{3}{|c}{ CATÉGORIES } \\
\cline { 2 - 4 } & "Extra" & I & II \\
\hline \multicolumn{1}{c|}{ Qualité commerciale } & Qualité supérieure & Bonne qualité & Qualité marchande \\
\hline $\begin{array}{l}\text { IV. Tolérances } \\
\text { (en nombre) }\end{array}$ & & & \\
- De qualité & $5 \%$ & $10 \%$ & $10 \%$ \\
$\begin{array}{l}\text { dont concombres } \\
\text { présentant une partie } \\
\text { terminale ayant un } \\
\text { goût amer }\end{array}$ & -- & -- & $2 \%$ \\
- Calibre & $10 \%$ & $10 \%$ & $10 \%$ \\
\end{tabular}

Toutefois, cette tolérance ne peut porter que sur des produits dont les dimensions et le poids s'écartent au maximum de 10 pour cent des limites fixées. 
TABLEAU COMPARATIF RESUME DES DISPOSITIONS DE LA NORME

\begin{tabular}{|c|c|c|c|}
\hline \multirow{2}{*}{ DISPOSITIONS } & \multicolumn{3}{|c|}{ CATÉGORIES } \\
\hline & "Extra" & 1 & II \\
\hline Qualité commerciale & Qualité supérieure & Bonne qualité & Qualité marchande \\
\hline $\begin{array}{l}\text { V. Présentation } \\
\text { (toutes catégories) }\end{array}$ & \multirow{3}{*}{\multicolumn{3}{|c|}{$\begin{array}{l} \\
\text { - origine } \\
\text { - variété ou type commercial } \\
\text { - qualité } \\
\text { - calibre (en cas de calibrage) } \\
\text { - la partie apparente du contenu du colis doit être } \\
\text { représentative de l'ensemble } \\
\text { - assure une protection convenable du produit les } \\
\text { concombres doivent être suffisamment serrés dans } \\
\text { l'emballage pendant le transport } \\
\text { - matériaux à l'intérieur du colis propres et d'une qualité } \\
\text { telle qu'elle permette d'éviter toute altération interne } \\
\text { ou externe } \\
\text { - l'encre ou la colle utilisées pour l'impression ou } \\
\text { l'étiquetage ne doivent pas être toxiques } \\
\text { - exempt de tout corps étranger } \\
\text { - les autocollants apposés individuellement sur les produits } \\
\text { doivent être tels qu'ils ne laissent aucune trace visible de } \\
\text { colle ni n'endommagent l'épiderme lorsqu'ils sont retirés } \\
\text { - les concombres recourbés doivent être emballés séparément }\end{array}$}} \\
\hline - Homogénéité & & & \\
\hline - Conditionnement & & & \\
\hline $\begin{array}{l}\text { VI. Marquage } \\
\text { (toutes catégories) }\end{array}$ & \multicolumn{3}{|c|}{$\begin{array}{l}\text { - identification de l'emballeur et/ou de l'expéditeur } \\
\text { - "concombres" si le contenu n'est pas visible de } \\
\text { l'extérieur } \\
\text { - "concombres recourbés", le cas échéant } \\
\text { - pays d'origine (indication de la région facultative) } \\
\text { - catégorie de qualité } \\
\text { - calibre (en cas de calibrage) exprimé par les poids } \\
\text { minimal et maximal } \\
\text { - nombre de pièces (facultatif) } \\
\text { - marque officielle de contrôle (facultatif) }\end{array}$} \\
\hline
\end{tabular}


Dans les pages suivantes, le texte officiel de la norme est indiqué en bleu gras ; Le texte interprétatif de la norme est indiqué en noir. 


\section{DEFINITION DU PRODUIT}

La présente norme vise les concombres des variétés (cultivars) issues du Cucumis sativus L. destinés à être livrés à l'état frais au consommateur, à l'exclusion des concombres destinés à la transformation industrielle et des cornichons.

Les variétés des concombres varient en ce qui concerne la forme, le calibre et l'épiderme. $\Rightarrow$ photos 1 à 2

Il n'y a pas de définition spéciale pour les concombres destinés à la transformation industrielle, néanmoins le cornichons sont des types variétal produisant au moins 85 unités par kilogramme. $\Rightarrow$ photo 3 


\section{DISPOSITIONS CONCERNANT LA QUALITE}

La norme a pour objet de définir les qualités que doivent présenter les concombres au stade du contrôle à l'exportation, après conditionnement et emballage.

Toutefois, aux stades suivant celui de l'exportation, les produits peuvent présenter, par rapport aux prescriptions de la norme :

- une légère diminution de l'état de fraîcheur et de turgescence.

- pour les produits classés dans les catégories autres que la catégorie "Extra", de légères altérations dues à leur évolution et à leur caractère plus ou moins périssable.

Le détenteur/vendeur des produits ne peut exposer ces produits en vue de la vente, les mettre en vente, les vendre, les livrer ou les commercialiser de toute autre manière que s'ils sont conformes à cette norme. Il est responsable du respect de cette conformité.

\section{A. Caractéristiques minimales}

Dans toutes les catégories, compte tenu des dispositions particulières prévues pour chaque catégorie et des tolérances admises, les concombres doivent être :

\section{- entiers.}

Les concombres doivent être sans atteinte ou ablation affectant l'intégrité du produit. $\Rightarrow$ photos 4 à 5

- sains; sont exclus les produits atteints de pourriture ou d'altérations telles qu'elles les rendraient impropres à la consommation.

Les concombres doivent être exempts de maladies ou de défauts prononcés affectant notablement leur aspect, leur comestibilité ou leur valeur commerciale. En particulier, cela exclut les concombres pourris, même si les signes de pourriture sont très légers, mais risquent de rendre les concombres impropres à la consommation une fois arrivés sur leur lieu de destination.

Sont exclus par conséquent les concombres qui présentent les défauts suivants :

a) meurtrissures prononcées. $\Rightarrow$ photo 6

b) maladies. $\Rightarrow$ photos 7 à 12

c) dommages causés par des températures basses ou par le gel. $\Rightarrow$ photo 13

d) défauts physiologiques comme des concombres creux à cause de manque de l'eau atteignant la texture de la pulpe et la qualité gustative. 
- propres, pratiquement exempts de matières étrangères visibles.

Les concombres doivent être pratiquement dépourvus de traces apparentes de terre, de poussière, de résidus de produits de traitement ou d'autres matières étrangères visibles.

La présence de la fleur n'est pas regardée comme matière étrangère visible. Toutefois, il est recommandé de la enlever pour éviter la pourriture. $\Rightarrow$ photos 14 à 16

- d'aspect frais et fermes.

Les concombres manquants de d'aspect frais et ayant jauni sont exclus. $\Rightarrow$ photo 17

Les concombres doivent être fermes et turgescents. Les concombres manquant de fermeté et ayant un "collet mou" et/ou devenus ridés ou desséchés sont exclus. $\Rightarrow$ photo 18

\section{- pratiquement exempts de parasites.}

Les concombres doivent être pratiquement exempts d'insectes ou d'autres parasites. La présence de parasites peut porter atteinte à la présentation commerciale et à l'acceptation des concombres.

- exempts d'attaques de parasites qui altèrent la chair.

Les dommages causés par des parasites peuvent porter atteinte à l'apparence générale, aux possibilités de conservation et de consommation des concombres. $\Rightarrow$ photo 19

- sans goût amer (sous réserve de la disposition particulière admise pour la catégorie II au chapitre "IV. DISPOSITIONS CONCERNANT LES TOLERANCES").

L'amertume des concombres - lié au cucubitacines - est influencée non seulement par des paramètres génétiques mais encore par des paramètres environnementaux.

\section{- exempts d'humidité extérieure anormale.}

Cette disposition s'applique en cas d'humidité excessive, lorsque, par exemple, de l'eau stagne dans le colis, mais ne vise pas la condensation recouvrant les produits à la sortie d'un entrepôt ou véhicule frigorifique.

- exempts d'odeur et/ou de saveur étrangères.

Il s'agit en particulier de concombres qui auraient séjourné dans un local de stockage mal entretenu ou qui auraient été transportés dans un véhicule mal nettoyé, et notamment de ceux qui auraient pris l'odeur forte dégagée par d'autres produits entreposés dans le même local ou transportés dans le même véhicule. Toutefois, on s'attachera à n'utiliser comme élément de protection dans l'emballage que des matériaux non-odorants. 
Les concombres doivent avoir atteint un développement suffisant tout en ayant des graines tendres.

Les concombres étant insuffisamment développes sont pointus et sillonnés à la partie terminale. $\Rightarrow$ photo 20

Les concombres avec des graines développés peuvent être déformés. Il faut inspecter des concombres par coupure pour examiner si les graines développées ne sont plus tendres. $\Rightarrow$ photo 21

Le développement et l'état des concombres doivent être tels qu'ils leur permettent :

- de supporter un transport et une manutention et

- d'arriver dans des conditions satisfaisantes au lieu de destination. 


\section{B. Classification}

Les concombres font l'objet d'une classification en trois catégories définies ci-après :

\section{i) Catégorie "Extra"}

Les concombres classés dans cette catégorie doivent être de qualité supérieure. Ils doivent présenter les caractéristiques et la coloration typique de la variété et/ou du type commercial.

Les concombres classés dans cette catégorie doivent être de présentation très soignée. $\Rightarrow$ photos 22 et 40

Ils doivent être :

\section{- bien développés.}

- bien formés et pratiquement droits

(hauteur maximale de l'arc intérieur : $10 \mathrm{~mm}$ pour $10 \mathrm{~cm}$ de longueur du concombre). $\Rightarrow$ photo 23

Pour toutes les catégories, la courbure des concombres est déterminée par la mesure de la longueur des concombres et de la hauteur de l'arc intérieur. La longueur des concombres est mesurée en prenant la distance la plus courte entre la cicatrice pistillaire et la zone pédonculaire. La hauteur de l'arc correspond à la longueur de la plus grande distance entre une ligne reliant la cicatrice pistillaire et la zone pédonculaire, et l'arc intérieur du concombre. $\Rightarrow$ photo 24

Ils ne doivent pas présenter de défauts, y compris toutes déformations et, en particulier, celles dues au développement des graines, à l'exception de très légères altérations superficielles à condition que celles-ci ne portent pas atteinte à l'aspect général du produit, à sa qualité, à sa conservation et à sa présentation dans l'emballage.

Des très légers défauts superficiels peuvent apparaître en cours de culture, lors de la récolte, du stockage, du conditionnement ou du transport. $\Rightarrow$ photo 25 


\section{ii) Catégorie I}

Les concombres classés dans cette catégorie doivent être de bonne qualité. Ils doivent présenter les caractéristiques de la variété et/ou du type commercial.

Bien que les exigences qualitatives soient moins sévères pour la catégorie I que pour la catégorie "Extra", il n'en demeure pas moins que les concombres de la catégorie I doivent être soigneusement sélectionnés et présentés. $\Rightarrow$ photos 25 et 41

Ils doivent être :

- suffisamment développés.

- assez bien formés et pratiquement droits

(hauteur maximale de l'arc intérieur : $10 \mathrm{~mm}$ pour $10 \mathrm{~cm}$ de longueur du concombre).mum height of the inner arc: $10 \mathrm{~mm}$ per $10 \mathrm{~cm}$ of length of the cucumber). $\Rightarrow$ photos 23 à 24

Ils peuvent toutefois présenter les légers défauts suivants, à condition que ceux-ci ne portent pas atteinte à l'aspect général du produit, à sa qualité, à sa conservation et à sa présentation dans l'emballage :

- un léger défaut de forme, sauf s'il est dû au développement des graines. $\Rightarrow$ photos 27 à 28

- de légers défauts de coloration, mais la coloration claire de la partie du concombre qui a été en contact avec le sol pendant la croissance n'est pas considérée comme un défaut.

Un léger défaut de coloration peut être lié à une partie qui était couvert par une feuille. $\Rightarrow$ photo 29

— de légers défauts de l'épiderme, à condition qu'îls ne s'étendent pas.

De légers défauts de l'épiderme causés par le frottement, le thrips ou des crevasses cicatrisés sont admis. Des crevasses de croissance peuvent être lies aux défauts de forme et apparaissent plutôt à la courbure concave comme la courbure convexe pousse plus vite que la courbure concave. $\Rightarrow$ photos 30 à 32 


\section{iii) Catégorie II}

Cette catégorie comprend les concombres qui ne peuvent être classés dans les catégories supérieures mais correspondent aux caractéristiques minimales ci-dessus définies.

Les concombres classés dans cette catégorie doivent être de qualité marchande, de présentation convenable et aptes à la consommation humaine. $\Rightarrow$ photo 42

Ils peuvent présenter les défauts suivants, à condition de garder leurs caractéristiques essentielles de qualité, de conservation et de présentation :

- des défauts de forme, autres que ceux dus à un développement avancé des graines; sont admis les concombres légèrement recourbés dont l'arc intérieur présente une hauteur maximale de $20 \mathrm{~mm}$ pour $10 \mathrm{~cm}$ de longueur du concombre. $\Rightarrow$ photos 23 à 24 et 33

- des défauts de coloration couvrant jusqu'au tiers de la surface, mais la coloration claire de la partie du concombre qui a été en contact avec le sol pendant la croissance n'est pas considérée comme un défaut. $\Rightarrow$ photo 34

— des défauts de l'épiderme, à condition qu'îls ne s'étendent pas. $\measuredangle>$ photos 35 à 37

Les concombres recourbés dont l'arc intérieur présente une hauteur supérieure à $20 \mathrm{~mm}$ pour $10 \mathrm{~cm}$ de longueur du concombre sont admis à condition qu'ils ne présentent que de légers défauts de coloration, à l'exclusion de tout autre défaut et de toute déformation autre que la courbure, et qu'ils soient conditionnés à part. $\Rightarrow$ photos 38 à 39

Les concombres présentant une déformation de forme sérieuse autre que la courbure mentionnée pour les concombres légèrement recourbés sont également considérés comme recourbés. 


\section{DISPOSITIONS CONCERNANT LE CALIBRAGE}

Le calibre est déterminé par le poids ou par l'association de la longueur et du diamètre.

Le calibrage est obligatoire pour les concombres des catégories "Extra" et I.

Afin de garantir un calibre homogène, l'une des deux options suivantes doit être appliquée :

(a) Concombres dont le calibre est déterminé par le poids

L'écart de poids entre les concombres d'un même colis ne doit pas excéder :

- $100 \mathrm{~g}$ lorsque la plus petite pièce pèse entre 180 et $400 \mathrm{~g}$;

- $150 \mathrm{~g}$ lorsque la plus petite pièce pèse $400 \mathrm{~g}$ ou plus ;

- Les concombres pesant moins de $180 \mathrm{~g}$ doivent être d'un calibre raisonnablement homogène.

(b) Concombres dont le calibre est détermine par la longueur et le diamètre

L'écart de longueur entre les concombres d'un même colis ne doit pas excéder :

- $5 \mathrm{~cm}$ entre le concombre le plus long et le concombre le plus court dans un même colis, et les concombres doivent avoir un diamètre raisonnablement homogène. 


\section{PROVISIONS CONCERNING TOLERANCES}

Des tolérances de qualité et de calibre sont admises dans chaque lot pour les produits non conformes aux exigences de la catégorie indiquée.

Les tolérances sont destinées à tenir compte de l'erreur humaine dans les opérations de classement qualitatif et de conditionnement. Lors du classement qualitatif et du calibrage, il n'est pas admis d'inclure à dessein les produits non conformes à la qualité requise, c'est-à-dire d'exploiter délibérément les tolérances.

Les tolérances sont déterminées après examen de chaque colis échantillon et par la moyenne d'ensemble des échantillons examinés. Les tolérances sont exprimées par le pourcentage, en nombre, de concombres de l'échantillon global non conformes à la catégorie ou au calibre indiqués sur le colis.

\section{A. Tolérances de qualité}

\section{i) Catégorie "Extra"}

Une tolérance totale de 5 pour cent, en nombre, de concombres ne correspondant pas aux caractéristiques de la catégorie, mais conformes à celles de la catégorie I est admise. Dans le cadre de cette tolérance, pas plus de 0,5 pour cent au total de produit correspondant aux caractéristiques de qualité de la catégorie II.

\section{ii) Catégorie I}

Une tolérance totale de 10 pour cent, en nombre, de concombres ne correspondant pas aux caractéristiques de la catégorie, mais conformes à celles de la catégorie II est admise. Dans le cadre de cette tolérance, pas plus de 1 pour cent au total de produit ne correspondant pas aux caractéristiques de qualité de la catégorie II ni aux caractéristiques minimales. Sont exclus les produits atteints de pourriture ou de toute autre altération les rendant impropres à la consommation.

\section{iii) Catégorie II}

Une tolérance totale de 10 pour cent, en nombre, de concombres ne correspondant pas aux caractéristiques de la catégorie ni aux caractéristiques minimales est admise. Sont exclus les produits atteints de pourriture ou de toute autre altération les rendant impropres à la consommation. Dans le cadre de cette tolérance, il est admis 2 pour cent au maximum en nombre de concombres pouvant présenter une petite partie terminale ayant un goût amer.

Au limite de la tolérance de la catégorie II, des concombres ayant un "collet mou" allant au dessus de "l'épaule" sont admis. 


\section{B. Tolérances de calibre}

Pour toutes les catégories (en cas de calibrage) : Une tolérance totale de 10 pour cent, en nombre, de concombres ne répondant pas aux exigences en ce qui concerne le calibrage est admise. Toutefois, cette tolérance ne peut porter que sur des produits dont les dimensions et le poids s'écartent au maximum de 10 pour cent des limites fixées.

Tolérance en ce qui concerne l'écart de calibre: $10 \%$ en nombre peuvent présenter un calibre s'écartant du calibre indiqué au colis, mais pas plus de 10\% du calibre indiqué. 


\section{DISPOSITIONS CONCERNANT LA PRESENTATION}

\section{A. Homogénéité}

Le contenu de chaque colis doit être homogène et ne comporter que des concombres de même origine, variété ou type commercial, qualité et calibre (dans la mesure où, en ce qui concerne ce dernier critère, un calibrage est imposé). $\Rightarrow$ photos 40 à 42

La partie apparente du contenu du colis doit être représentative de l'ensemble.

On veillera particulièrement à réprimer le "fardage", qui consiste à dissimuler dans les couches inférieures du colis les produits de qualité et de calibre moindres que ceux qui sont visibles et spécifiés par le marquage.

De même, est exclue toute méthode ou pratique de conditionnement visant à conférer à la couche supérieure visible du colis un aspect trompeur.

\section{B. Conditionnement}

Les concombres doivent être conditionnés de façon à assurer une protection convenable du produit.

Les concombres doivent être suffisamment serrés dans l'emballage de manière à éviter tout dommage durant le transport.

La qualité, la solidité et la conception des emballages doivent leur permettre de protéger les produits lors du transport et des manutentions.

En raison de protection, spécialement contre le perd de humidité à cause de transpiration et une certaine protection contre des températures bas, les concombres peuvent être emballés en film plastique. $\Rightarrow$ photo 43

Les matériaux utilisés à l'intérieur du colis doivent être propres et de nature à ne pas causer aux produits d'altérations externes ou internes. L'emploi de matériaux, et notamment de papiers ou timbres comportant des indications commerciales, est autorisé, sous réserve que l'impression ou l'étiquetage soient réalisés à l'aide d'une encre ou d'une colle non toxiques.

Il convient d'assurer une protection appropriée du produit à l'aide de matériaux neufs et propres à l'intérieur du colis et d'éviter que des corps étrangers tels que feuilles, sable ou terre ne nuisent à sa bonne présentation.

Les autocollants apposés individuellement sur les produits doivent être tels qu'ils ne laissent aucune trace visible de colle ni n'endommagent l'épiderme lorsqu'ils sont retirés.

Les colis doivent être exempts de tout corps étranger.

Le manque de propreté manifeste, constaté dans plusieurs colis, peut entraîner un refoulement de la marchandise. 


\section{DISPOSITIONS CONCERNANT LE MARQUAGE}

Chaque colis ${ }^{1}$ doit porter, en caractères groupés sur un même côté, lisibles, indélébiles et visibles de l'extérieur, les indications ci-après :

Dans le cas de conditionnement en colis, toutes les indications doivent êtres groupées sur un même côté du colis, soit sur une étiquette solidement fixée au colis, soit par impression directe à l'aide d'une encre résistant à l'eau . $\Rightarrow$ photos 44 à 45

Les colis de réemploi doivent avoir été soigneusement débarrassés de toutes les étiquettes précédemment fixées, et les mentions antérieures avoir été oblitérées.

\section{A. Identification}

\begin{tabular}{|c|c|}
\hline $\begin{array}{l}\text { Emballeur } \\
\text { et/ou } \\
\text { Expéditeur }\end{array}$ & $\begin{array}{l}\text { Nom et adresse (par exemple, rue/ville/région/code postal, } \\
\text { et pays s'il est différent du pays d'origine) ou identification } \\
\text { symbolique reconnue officiellement par l'autorité nationale. }{ }^{2}\end{array}$ \\
\hline
\end{tabular}

Aux fins du contrôle, le mot "emballeur" désigne la personne ou l'entreprise qui a la responsabilité du conditionnement des produits dans l'emballage (il ne s'agit pas en l'espèce du personnel d'exécution dont la responsabilité n'existe que devant l'employeur). L'identification symbolique s'entend non par référence à une marque commerciale, mais à un système contrôlé par un organisme officiel et permettant de reconnaître sans équivoque le responsable du conditionnement des produits dans l'emballage (la personne ou l'entreprise). Toutefois, la responsabilité peut être volontairement ou obligatoirement assumée par l'expéditeur seul vis-à-vis du contrôle et dans ce cas, l'identification de "l'emballeur" au sens ci-dessus défini n'est plus nécessaire.

Pour éviter toute confusion lorsqu'un code (une identification symbolique) est utilisé, la mention "emballeur" et/ou "expéditeur" (ou une abréviation équivalente, par exemple “emb.", "exp.”) doit être indiquée à proximité de ce code.

1. Les emballages unitaires de produits préemballés destinés à la vente directe au consommateur ne sont pas soumis à ces règles de marquage mais doivent répondre aux dispositions nationales prises en la matière. En revanche, ces indications doivent, en toute état de cause, être apposées sur l'emballage de transport contenant ces unités.

2. Selon la législation nationale de certains pays, le nom et l'adresse doivent être indiqués explicitement. Toutefois, lorsqu'un code (identification symbolique) est utilisé, la mention "emballeur et/ou expéditeur (ou une abréviation équivalente)" doit être indiquée à proximité de ce code (identification symbolique) et celui-ci doit être précédé par le code ISO 3166 (alpha) de pays/zone correspondant au pays de l'autorité nationale, si celui-ci n'est pas le pays d'origine. 


\section{B. Nature du produit}

- "Concombres" si le contenu n'est pas visible de l'extérieur.

La mention du produit ne doit obligatoirement figurer que sur les colis fermés et si le contenu n'est pas visible de l'extérieur.

— “Concombres recourbés", le cas échéant.

C. Origine du produit

- Pays d'origine et, éventuellement, zone de production ou appellation nationale, régionale ou locale.

Le marquage devra mentionner le pays d'origine, c'est-à-dire le pays dans lequel les concombres ont été produits (par exemple : "Pays bas", "Espagne"). Eventuellement, la zone de production ou une appellation nationale, régionale ou locale peut également être indiquée.

\section{Caractéristiques commerciales}

- Catégorie.

L'indication de la catégorie est obligatoire.

- Calibre (en cas de calibrage) exprimé par les poids minimal et maximal.

L'écart du calibre doit être indiqué pour les catégories "Extra" et I et peut être indiqué pour la catégorie II dans le cas où les concombres de catégorie II sont calibrés.

- Nombre de pièces (facultatif).

E. Marque officielle de contrôle (facultative) 
photo 1: Definition of produce - Most common type of cucumbers grown under protection

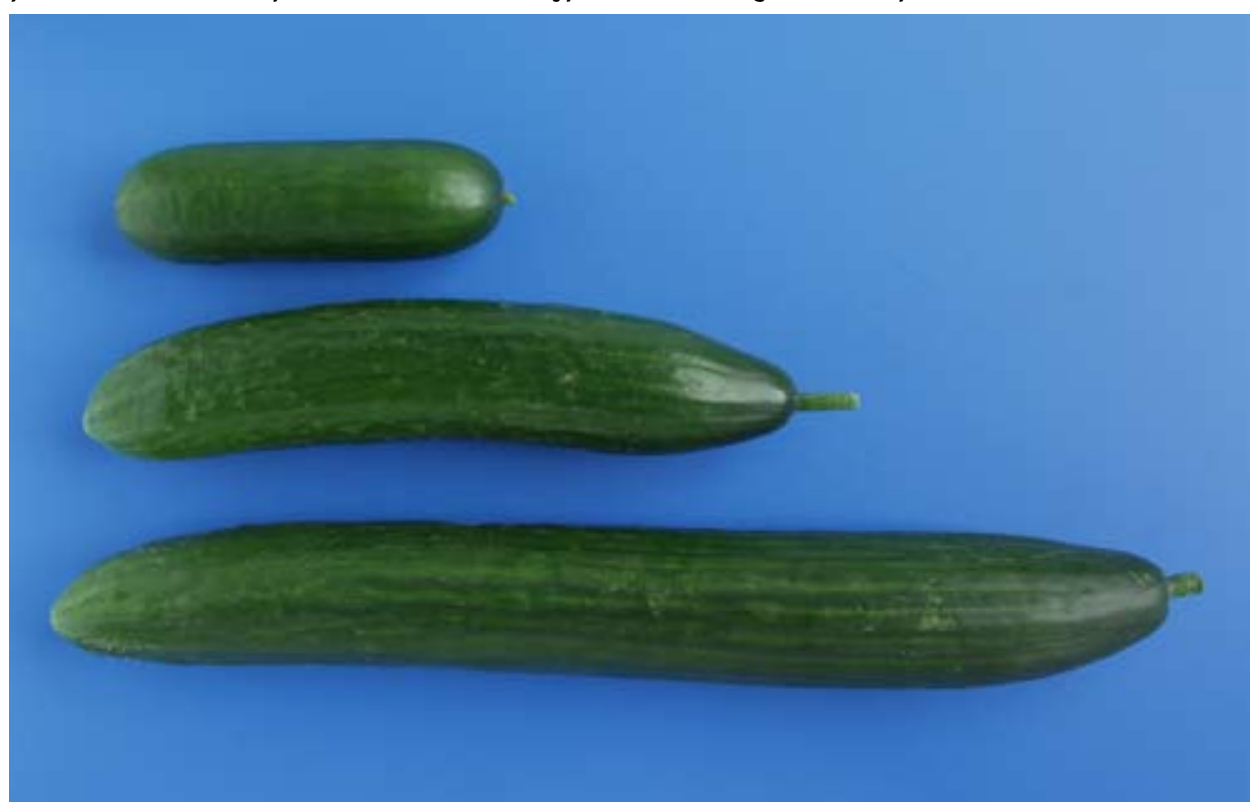

photo 1 : Définition du produit - Type de concombres le plus commun produit sous protection

photo 2: Definition of produce - Type of cucumbers usually grown in the open

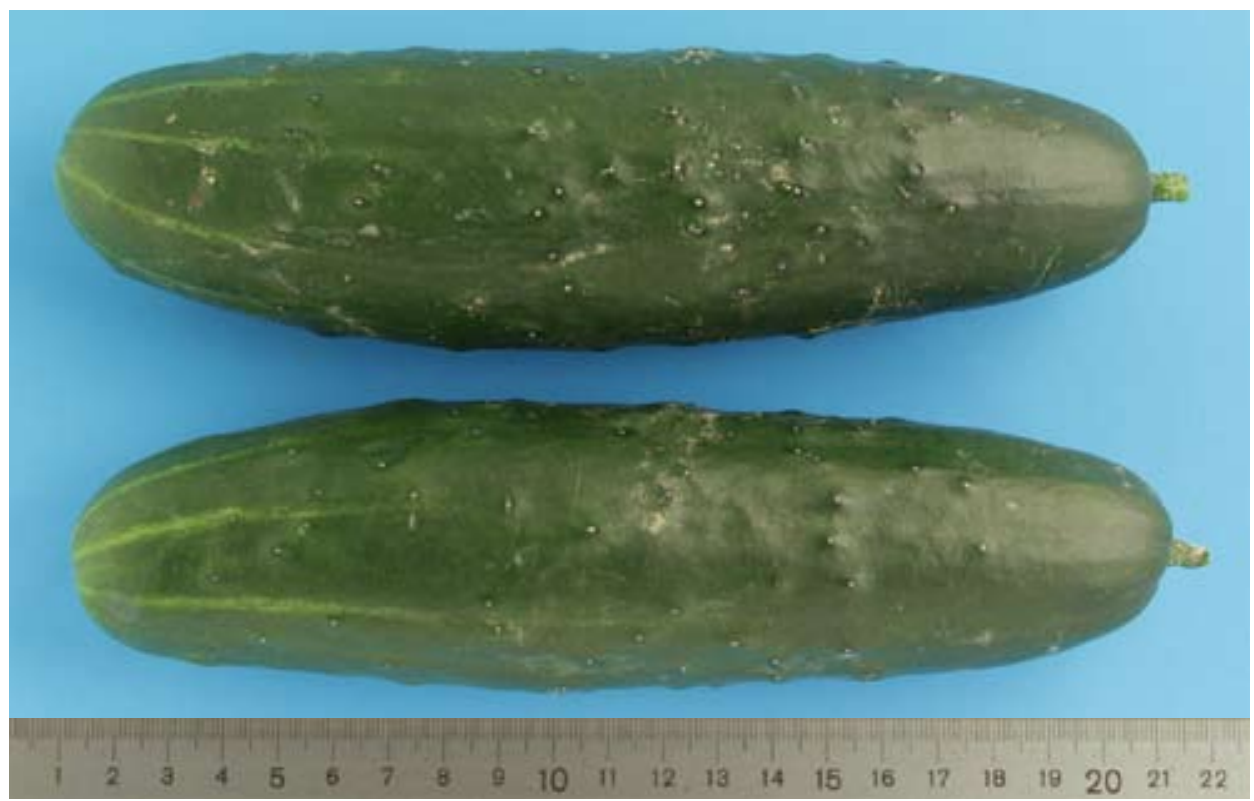

photo 2 : Définition du produit - Type de concombres cultivés normalement en plein air 
photo 3: Definition of produce - Types of cucumbers not covered by the standard Left: cucumbers for processing; Right: gherkins

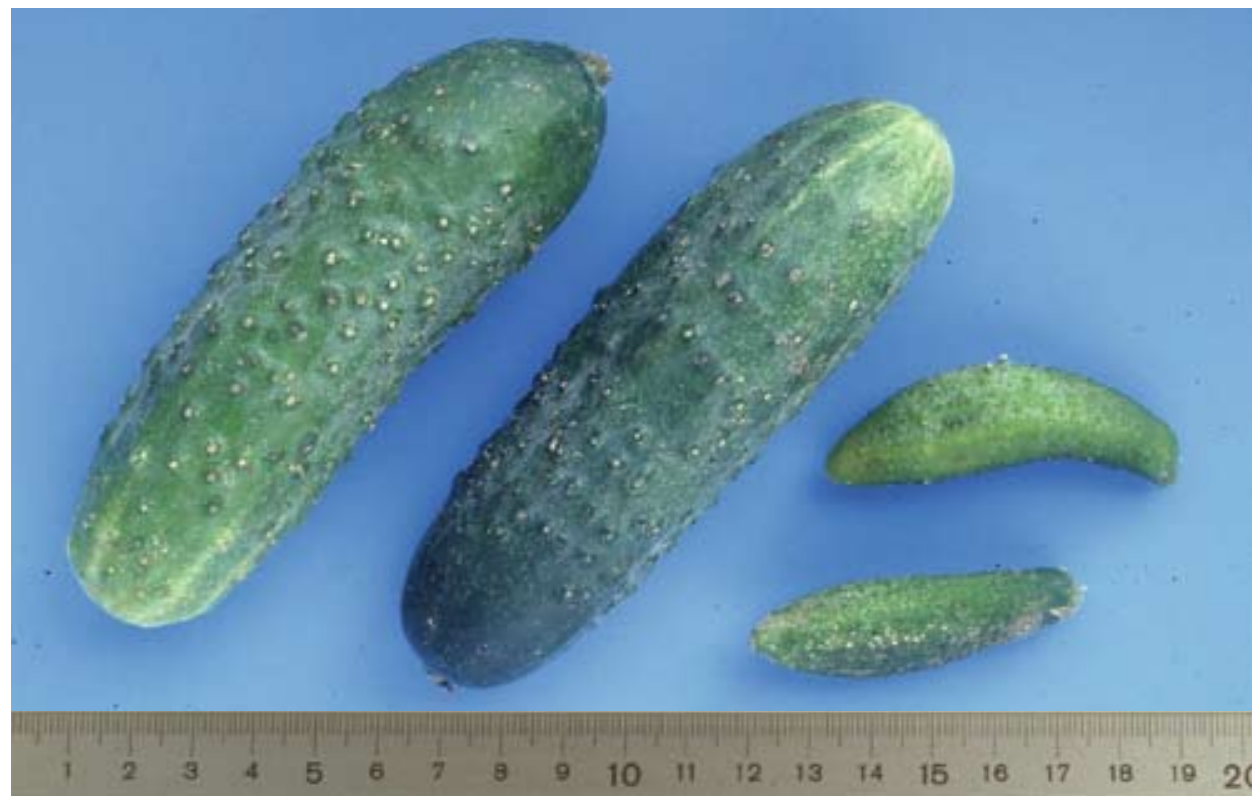

photo 3 : Définition du produit - Types de concombres pas visés par la norme À gauche : concombres pour la transformation; À droite : cornichons

photo 4: Minimum requirement "intact" - Damage due to torn out peduncle - Not allowed

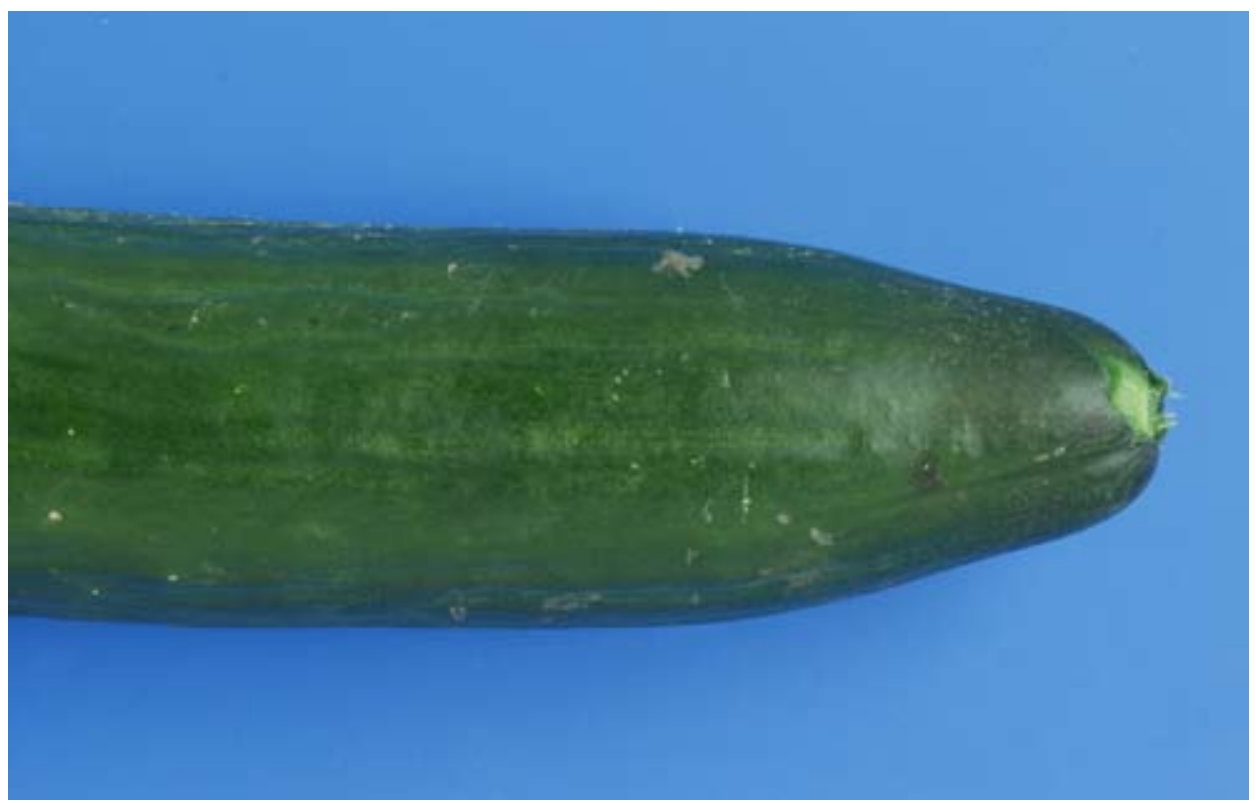

photo 4 : Caractéristique minimale "entier" - Dommage causé par pédoncule arraché - Exclu 
photo 5: Minimum requirement "intact" - Cutting damage - Not allowed

photo 5 : Caractéristique minimale "entier" - Coupure - Exclu

photo 6: Minimum requirement "intact" - Severe bruises - Not allowed

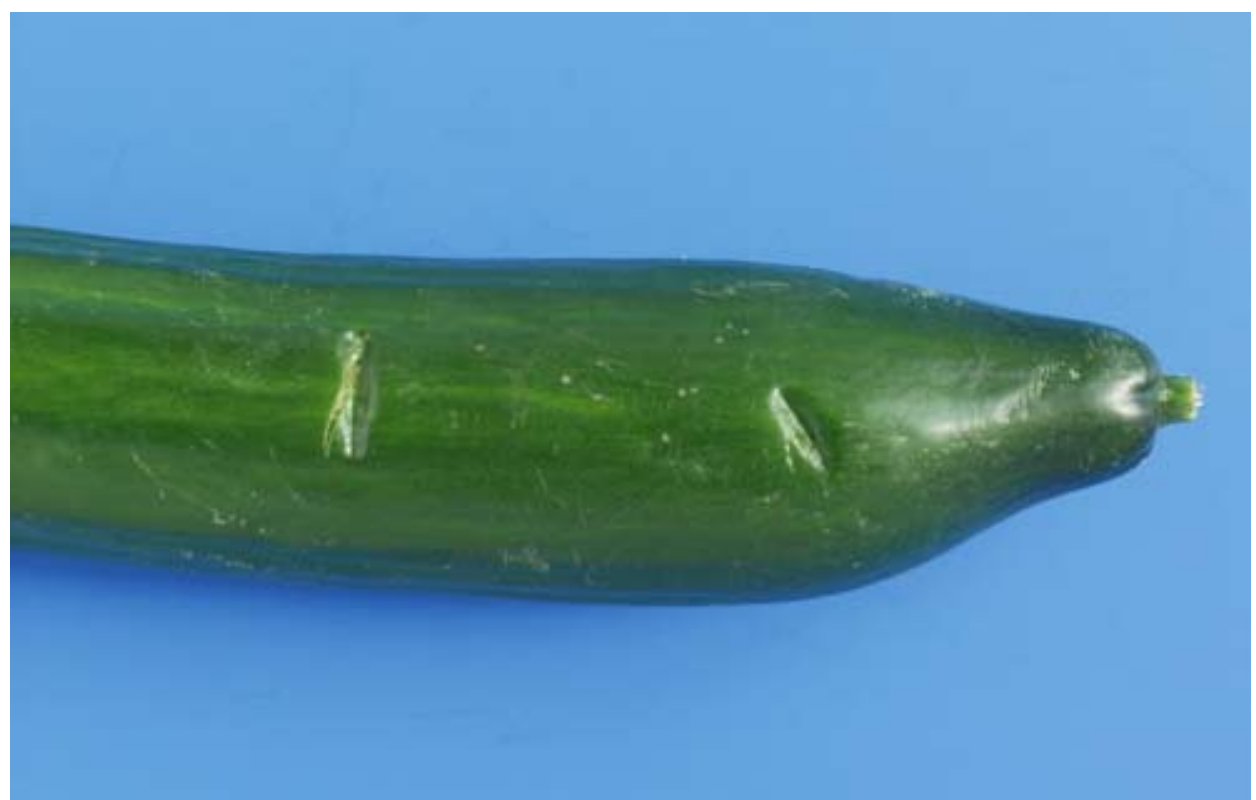

photo 6 : Caractéristique minimale "entier" - Meurtrissures prononcées - Exclu 
photo 7: Minimum requirement "sound" - Gummy stem blight (Didymella bryoniae = Mycosphaerella itrullina) External and internal aspect - Not allowed

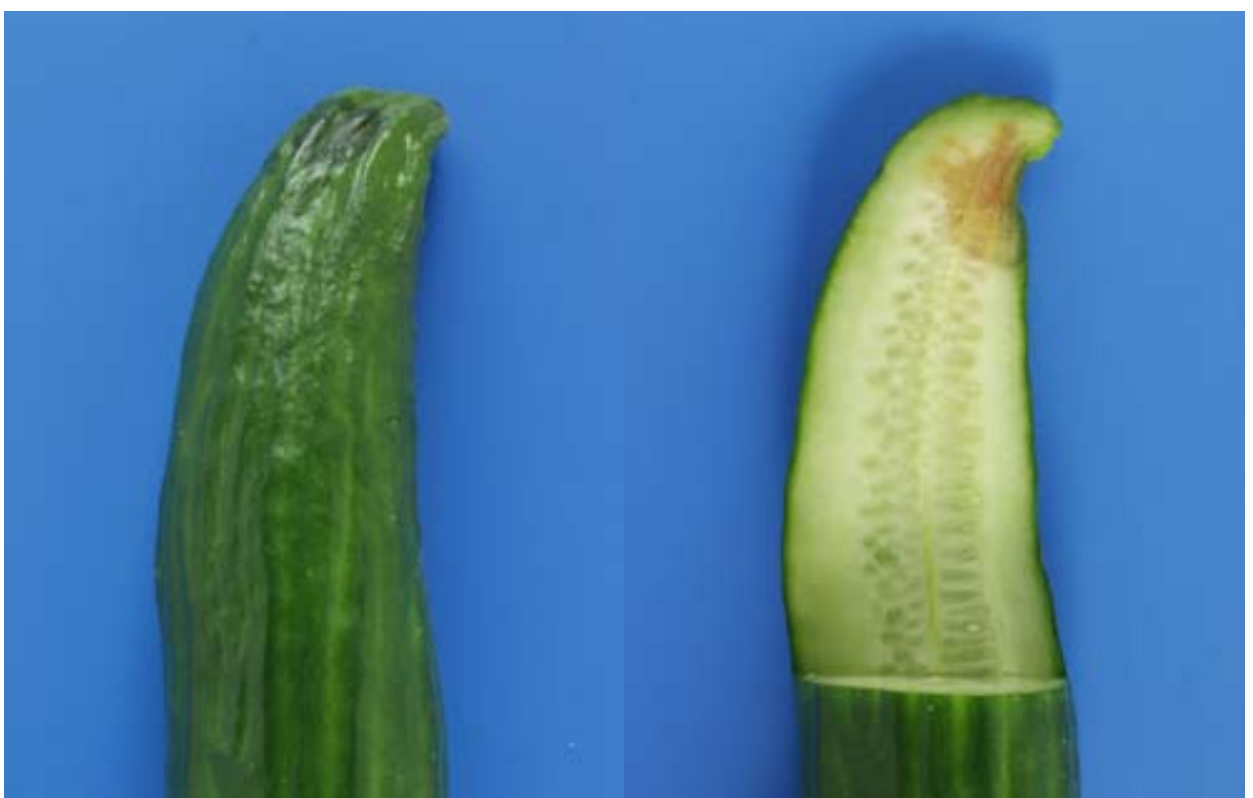

photo 7 : Caractéristique minimale "sain" - Pourriture noire (Didymella bryoniae = Mycosphaerella citrullina) Aspect externe et interne - Exclu

photo 8: Minimum requirement "sound" - Scab (Cladosporium cucumerinum) - Not allowed

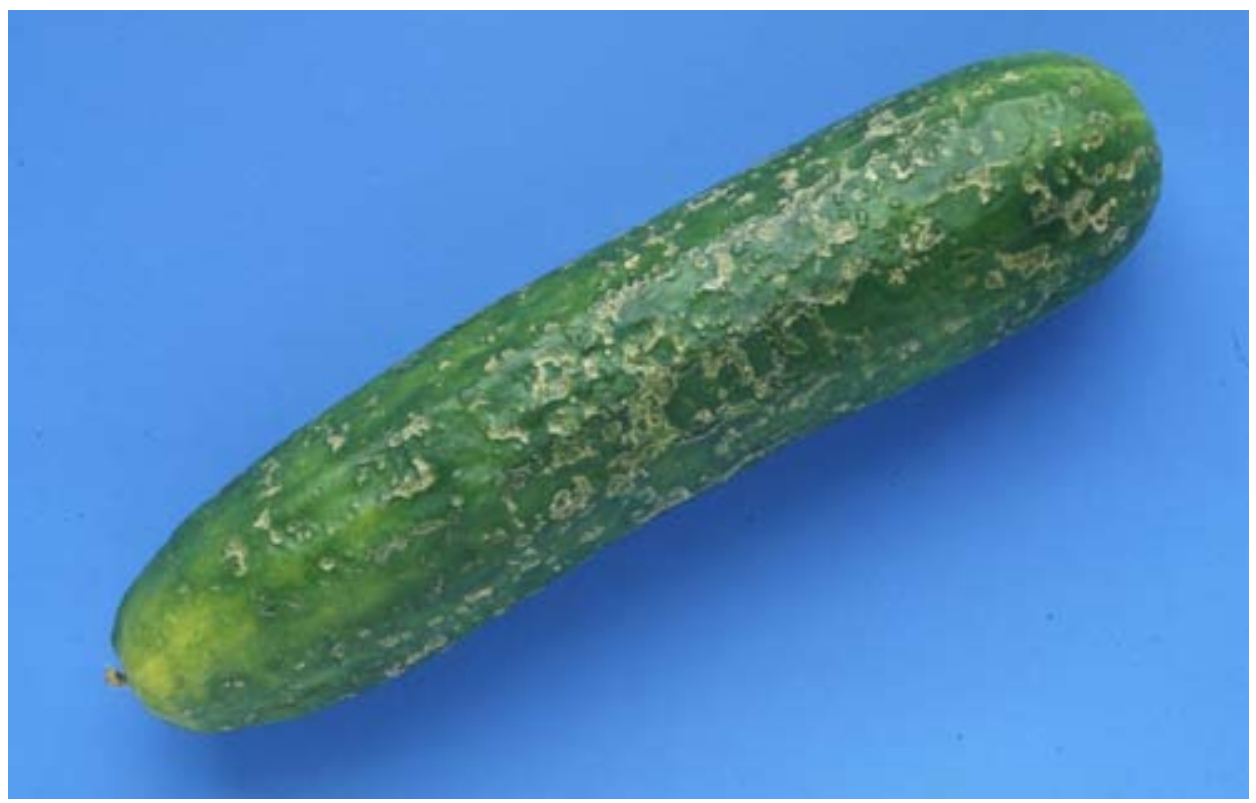

photo 8 : Caractéristique minimale "sain" - Gale (Cladosporium cucumerinum) - Exclu 
photo 9: Minimum requirement "sound" - Virus disease - Not allowed

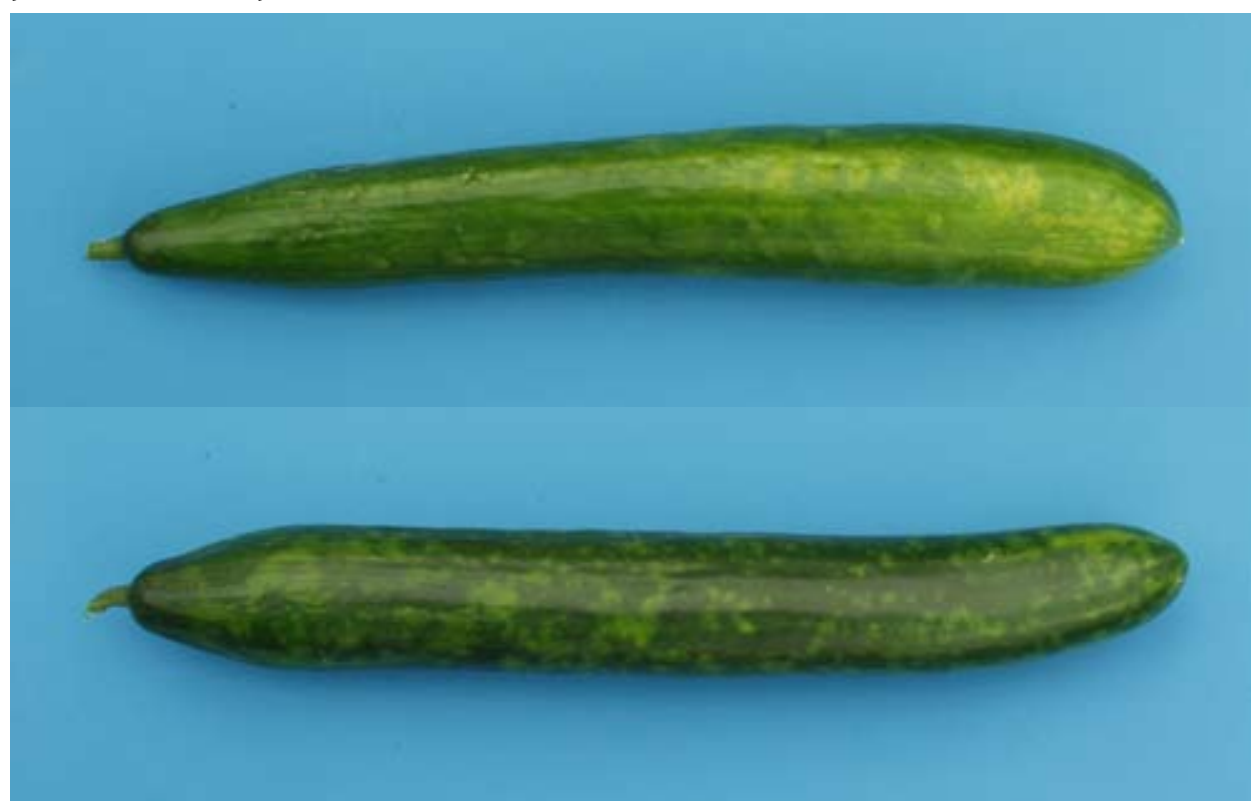

photo 9 : Caractéristique minimale "sain" - Virose - Exclu

photo 10: Minimum requirement "sound" - Watery soft rot (Sclerotinia sclerotiorum) - Not allowed

photo 10 : Caractéristique minimale "sain" - Pourriture sclérotique (Sclerotinia sclerotiorum) - Exclu 
photo 11: Minimum requirement "sound" - Grey mould (Botrytis cinerea) on flower remains and cucumbers Not allowed

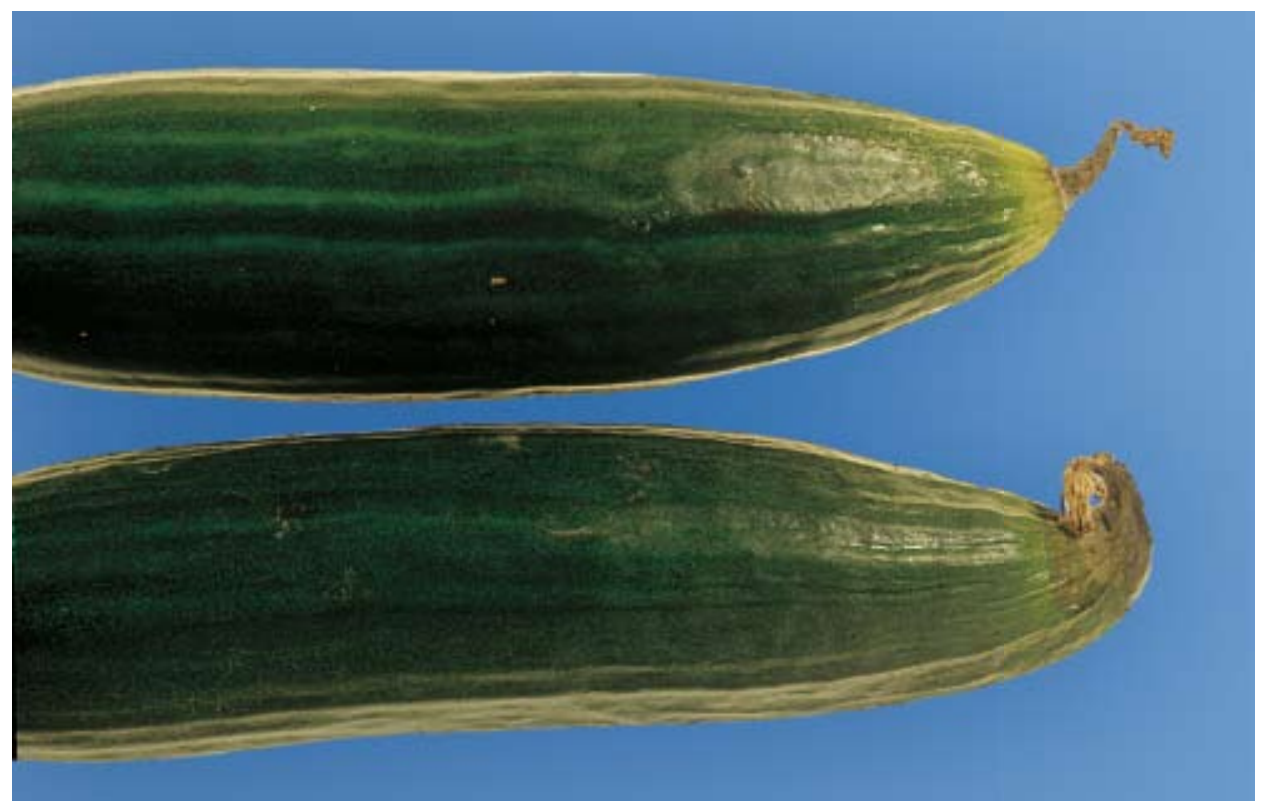

photo 11 : Caractéristique minimale "sain"

Moisissure grise (Botrytis cinerea) en résidu de fleurs et concombres - Exclu

photo 12: Minimum requirement "sound" - Gum exudation - Not allowed

photo 12 : Caractéristique minimale "sain" - Excrétion gommeuse - Exclu 
photo 13: Minimum requirement "sound" - Chilling injury - Not allowed

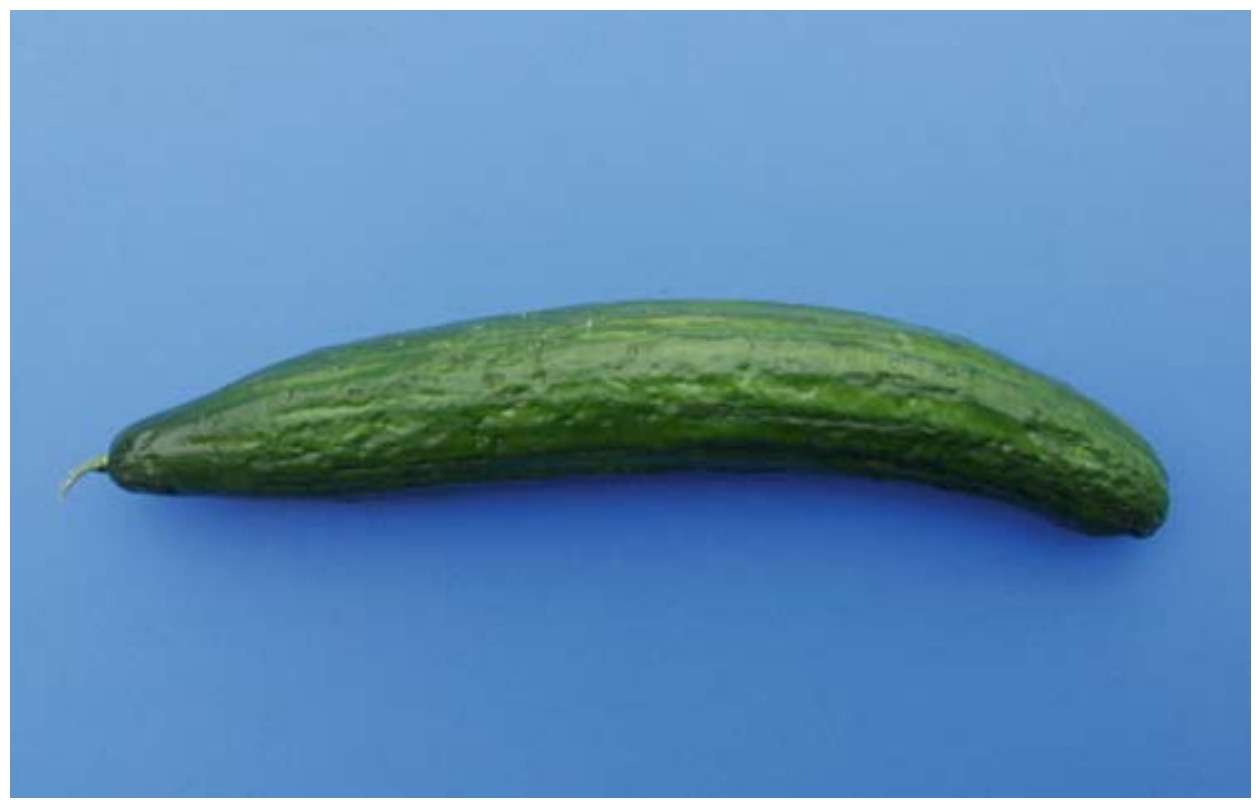

photo 13 : Caractéristique minimale "sain" - Défauts causés par le froid - Exclu

photo 14: Minimum requirement "clean" - Cucumbers not free of visible foreign matter - Not allowed

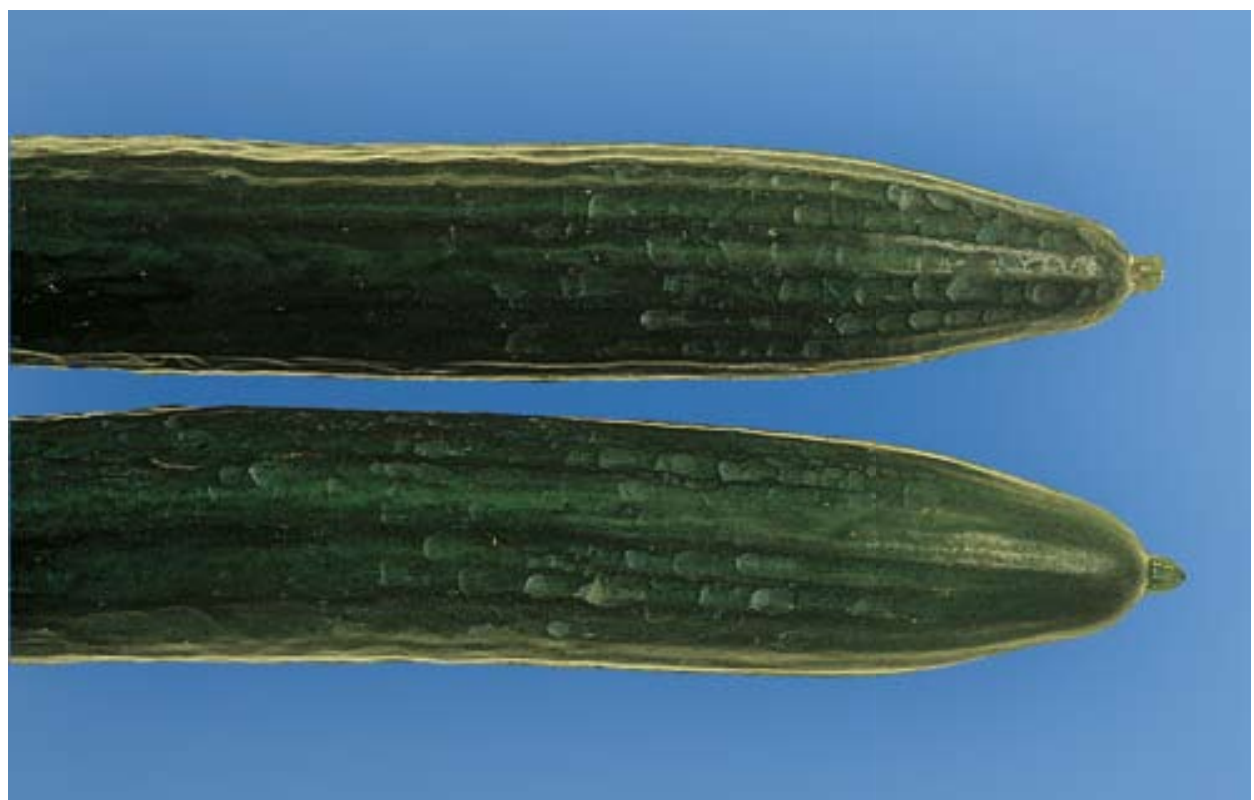

photo 14 : Caractéristique minimale "propre" - Concombres pas exempts de matière étrangère visible - Exclu 
photo 15: Minimum requirement "clean" - Soiled cucumber - Not allowed

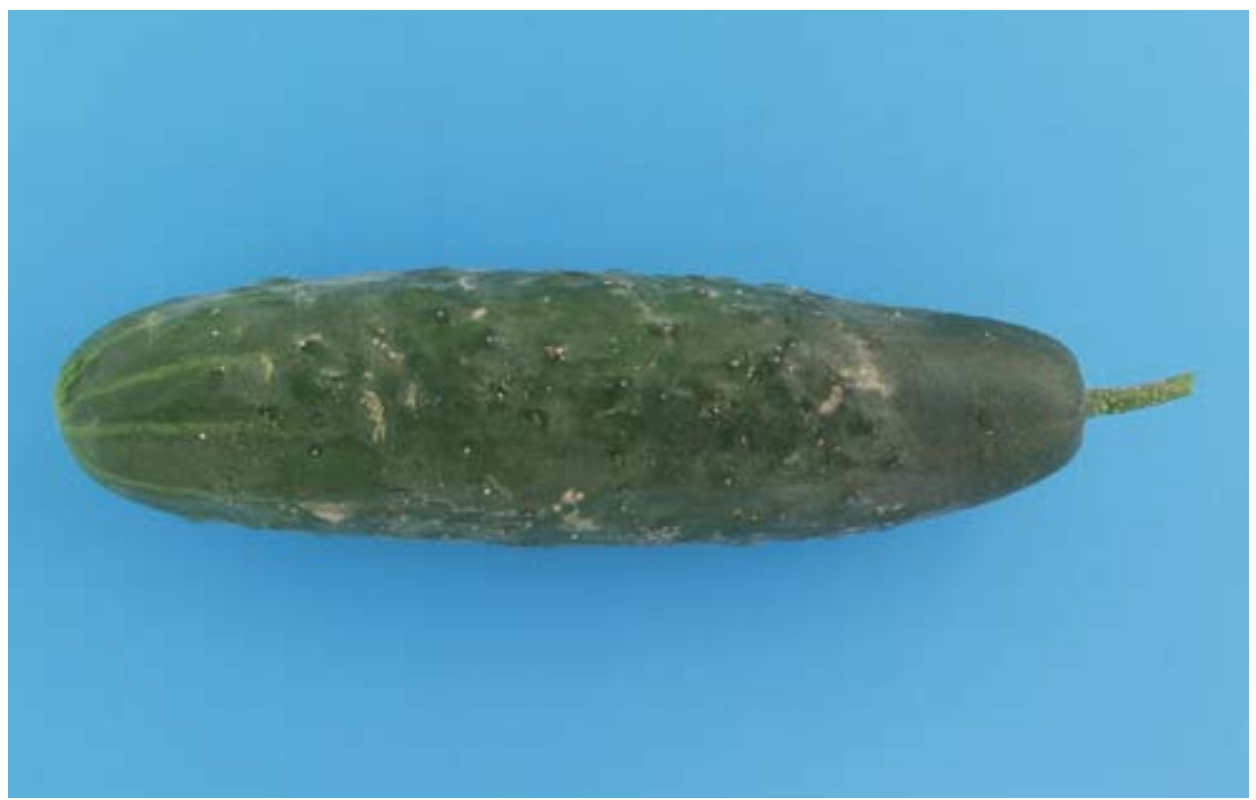

photo 15 : Caractéristique minimale "propre" - Concombre souillé par de la terre - Exclu photo 16: Minimum requirement "clean" - Sooty mould - Not allowed 
photo 17: Minimum requirement "fresh in appearance and firm"

Yellow discoloration due to lack of freshness - Not allowed

photo 17 : Caractéristique minimale "d'aspect fraîche et ferme"

Concombre jauni à cause d'une manque de fraîcheur - Exclu

photo 18: Minimum requirement "fresh in appearance and firm"

Yellow discoloration due to lack of freshness - Not allowed

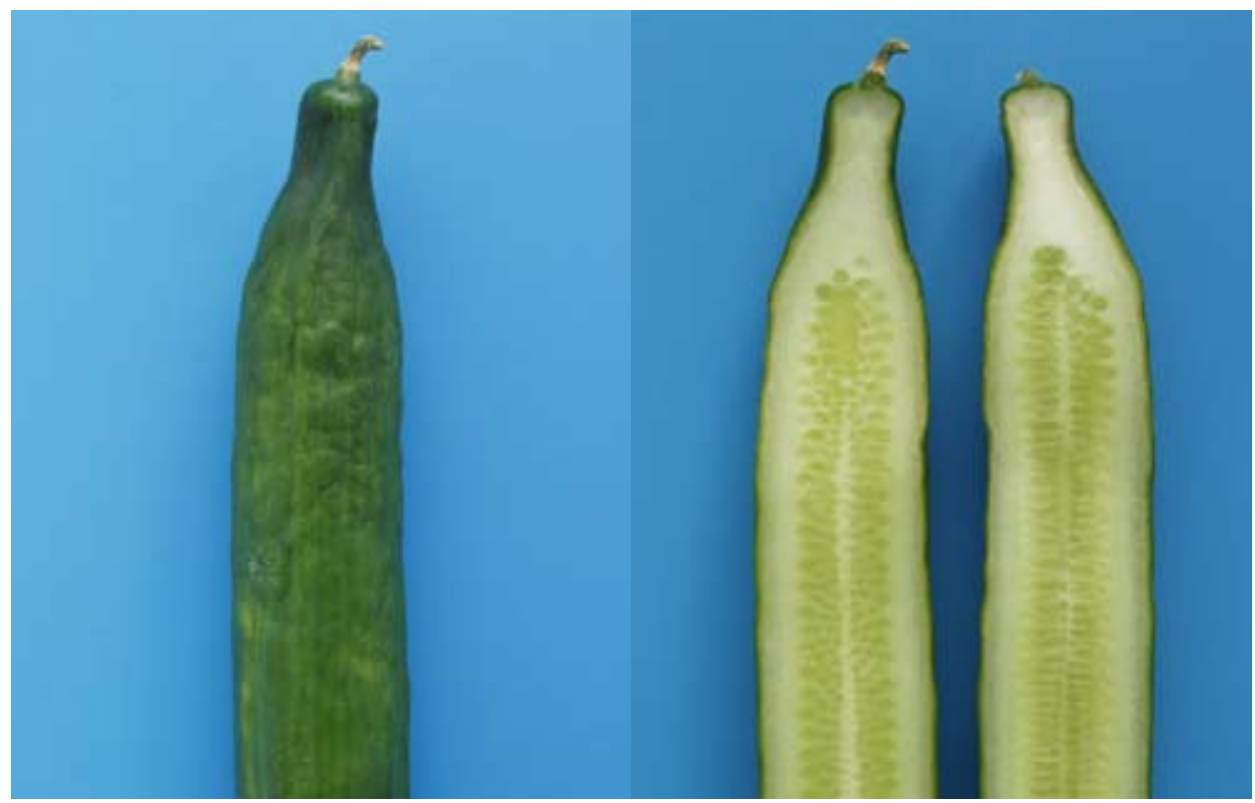

photo 18 : Caractéristique minimale "d'aspect fraîche et ferme" Concombre ridé - aspect externe et interne - Exclu 
photo 19: Minimum requirement "free of damage caused by pest affecting the flesh" Slug damage - Not allowed

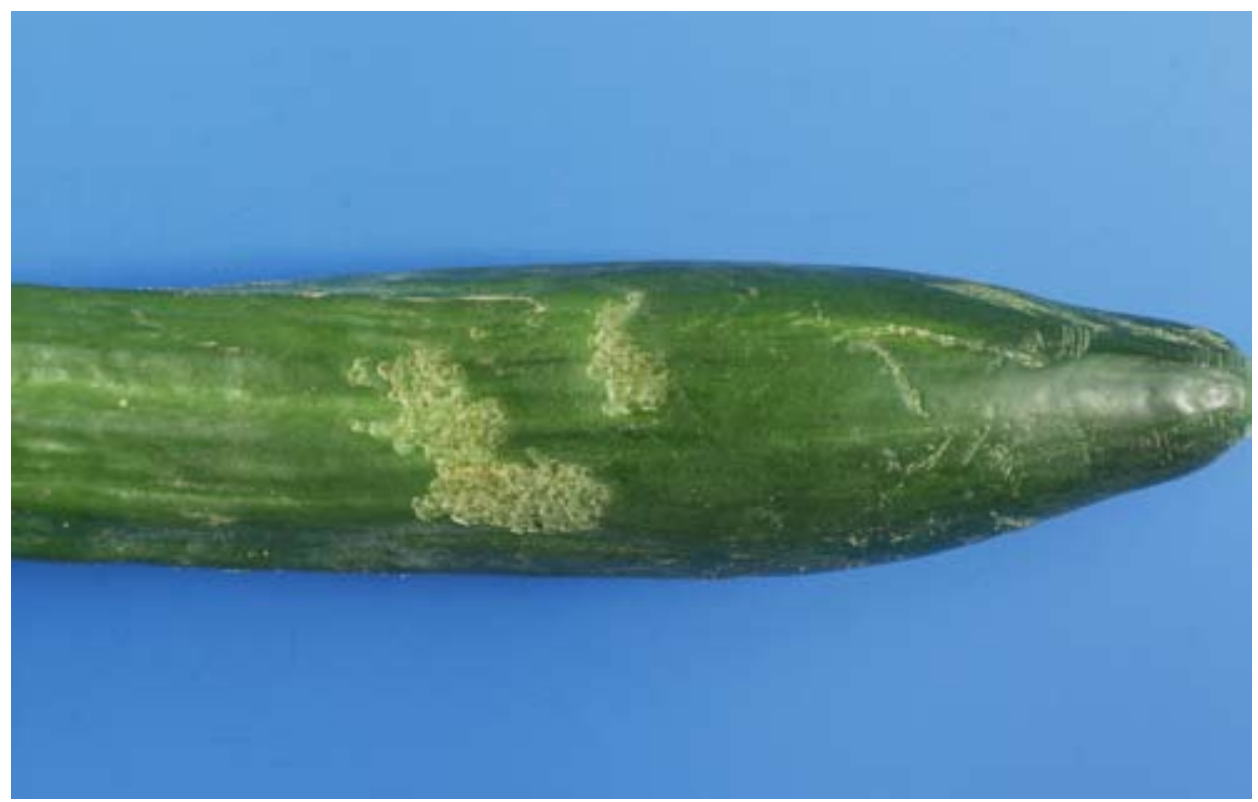

photo 19 : Caractéristique minimale "exempts d'attaques de parasites qui altèrent la chair" Dommages causés par de limaces - Exclu

photo 20: Minimum requirement "sufficiently developed"

Not sufficiently developed cucumbers - Not allowed

photo 20 : Caractéristique minimale "suffisamment développé"

Concombres insuffisamment développés - Exclu 
photo 21: Minimum requirement "sufficiently developed, but seeds must be soft" Cucumber with hard seeds - Not allowed

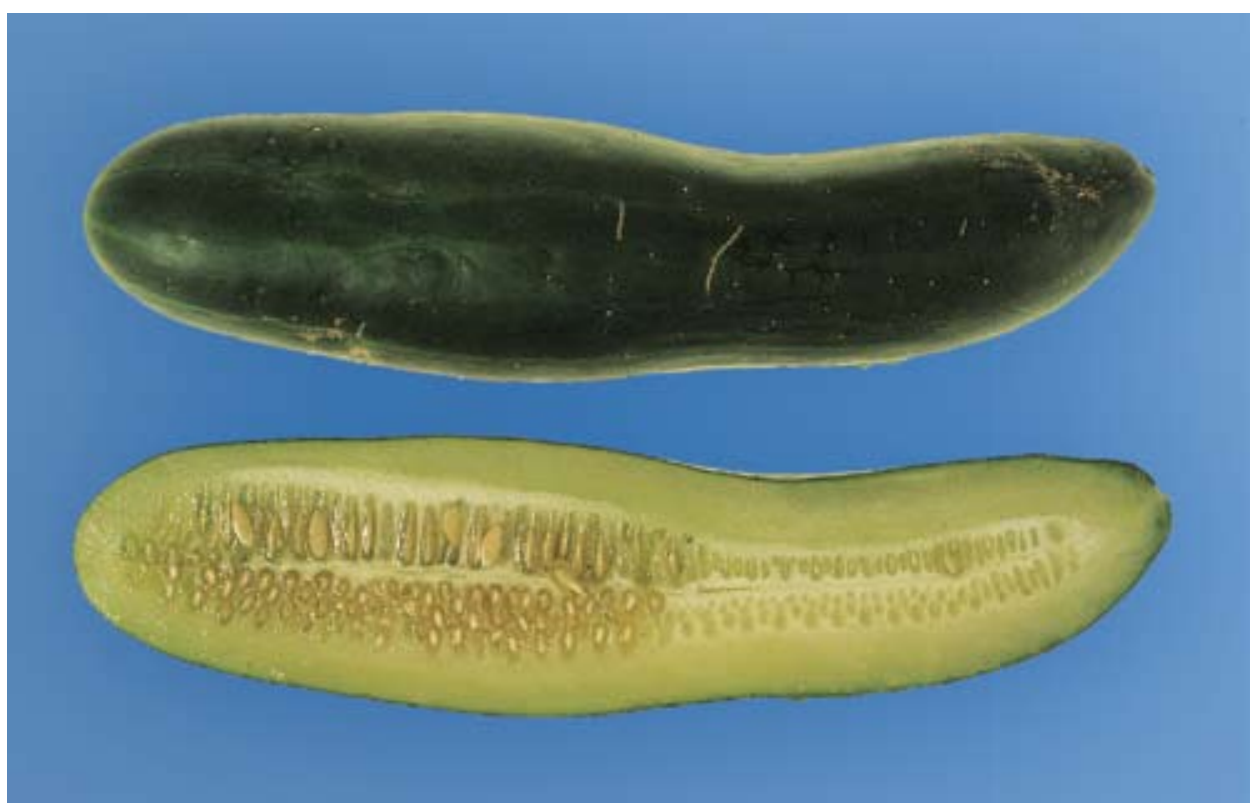

photo 21 : Caractéristique minimale "suffisamment développé ayant des graines tendres" Concombre avec graines dures - Exclu

photo 22: "Extra" Class - Perfect cucumbers, well shaped and practically straight

photo 22 : Catégorie "Extra" - Concombres parfaits, bien formés et pratiquement droits 
photo 23: Maximum height of the arc - Top: practically straight

Middle: Limit allowed for Classes "Extra" and I - Bottom: Limit allowed for Class II

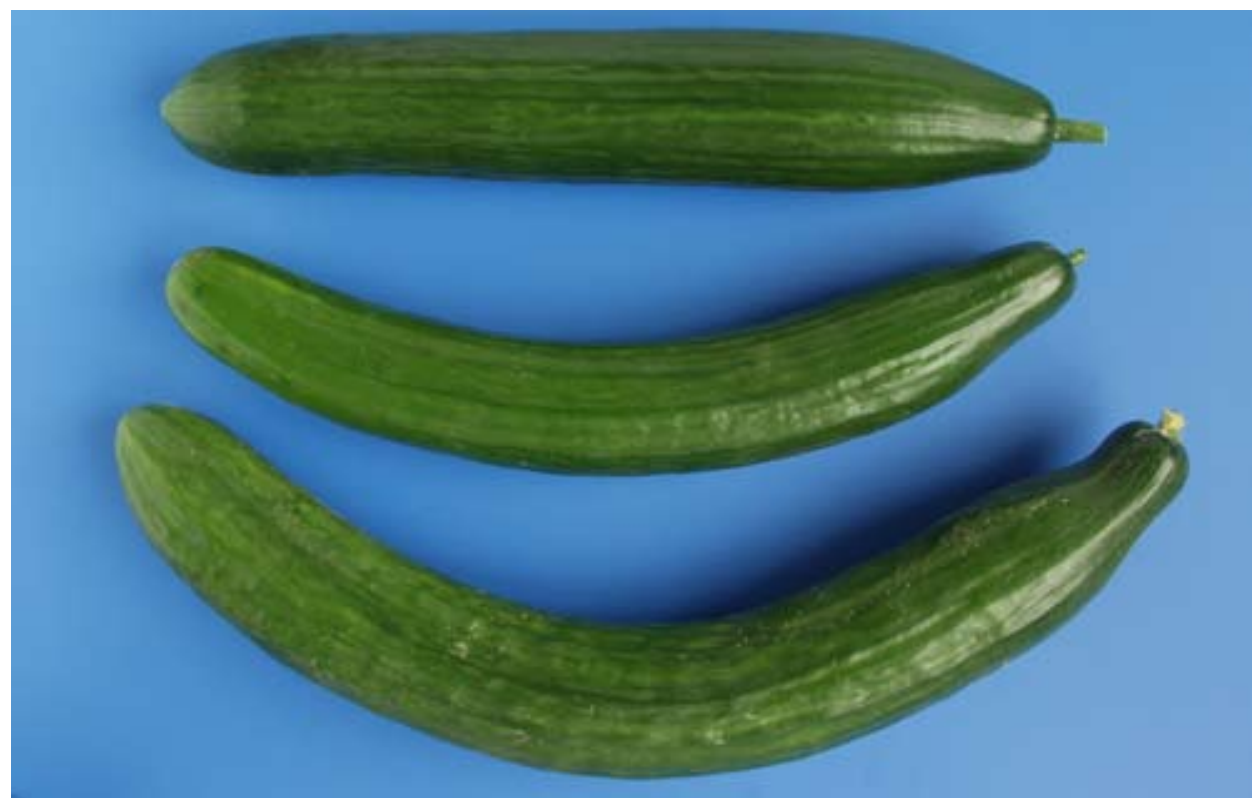

photo 23 : Hauteur maximale de l'arc - En haut: pratiquement droit

Au milieu: limite admise pour les catégories "Extra" et I - En bas: limite admise pour la catégorie II

photo 24: Diagram on how to measure the height of the arc

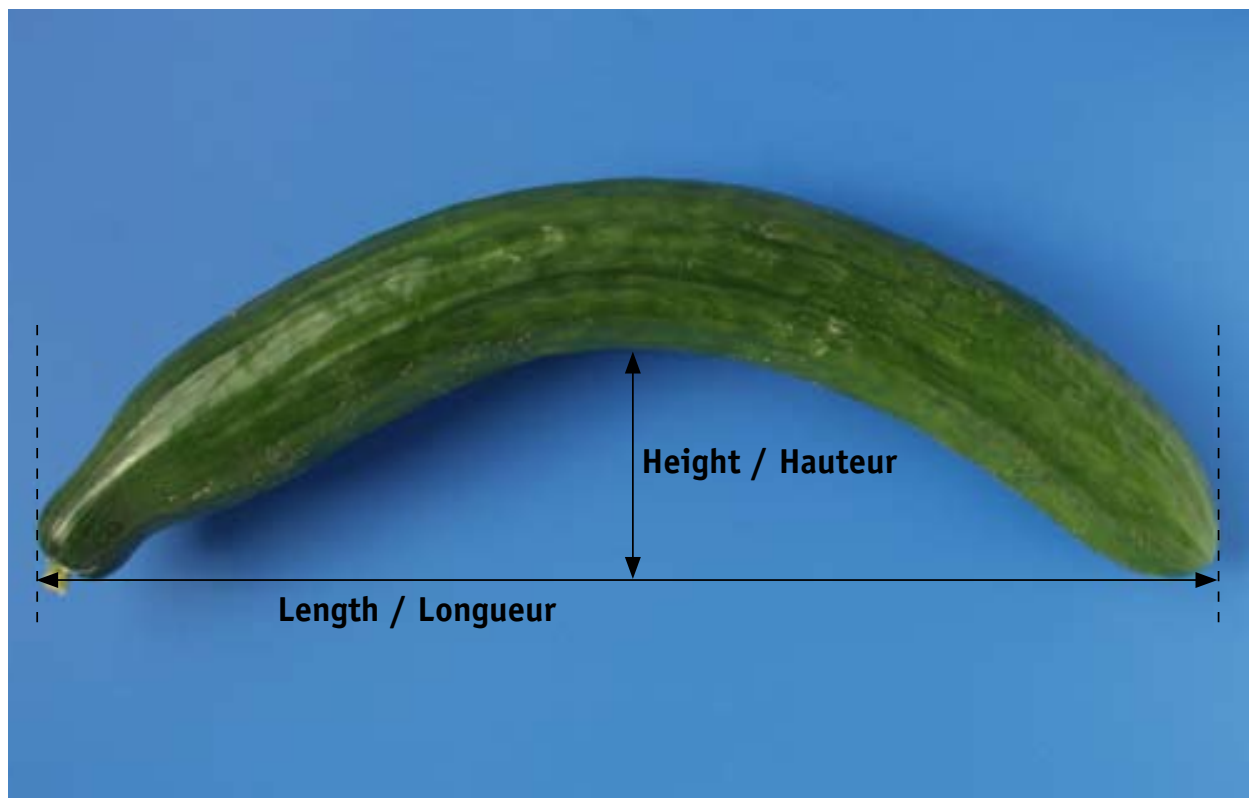

photo 24 : Schéma pour mesurer la courbure du concombre 
photo 25: "Extra" Class "Very slight superficial defects" - Very slight skin defects - Limit allowed

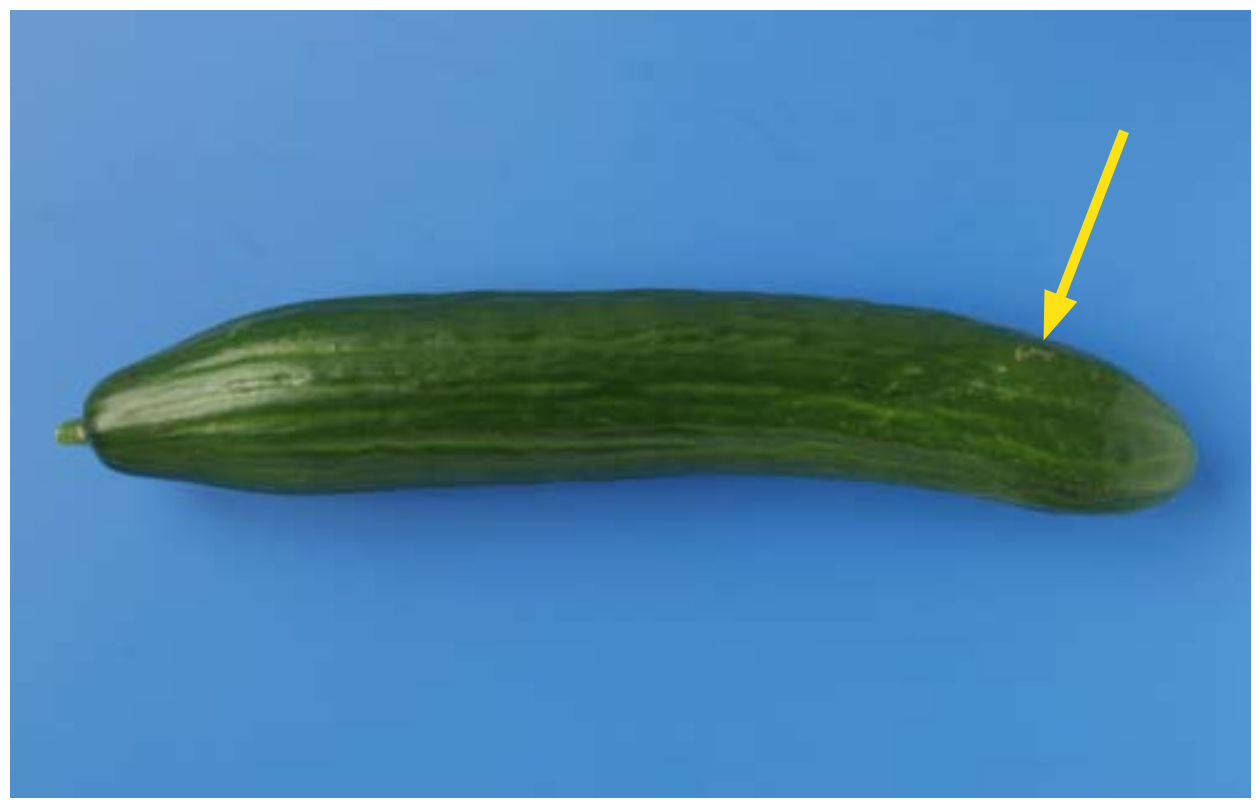

photo 25 : Catégorie "Extra", "Très légères altérations superficielles" - De très légers défauts de l'épiderme Limite admise

photo 26: Class I - Good quality cucumbers - reasonably well shaped and practically straight - Limit allowed

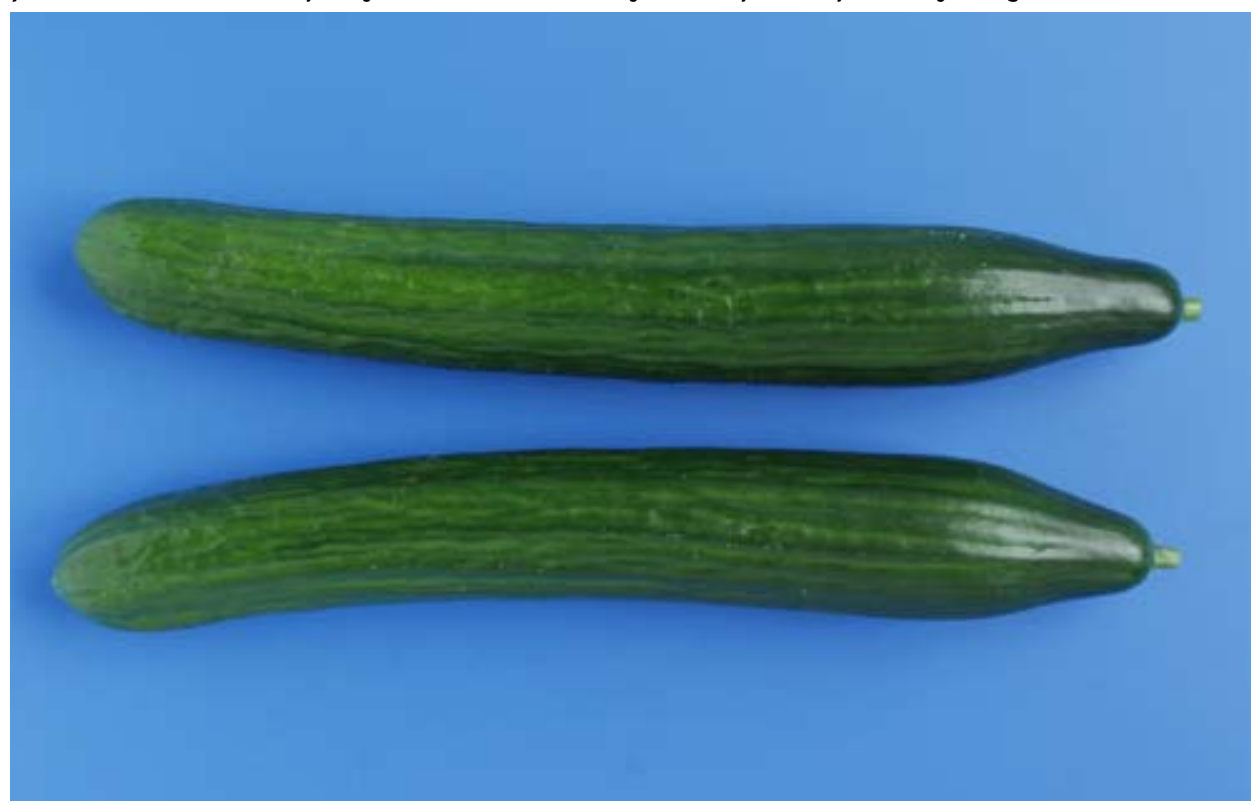

photo 26 : Catégorie I - Concombres de qualité bonne - assez bien formés et pratiquement droits - Limite admise 
photo 27: Class I "slight defect in shape" - Slight deformation - Limit allowed

photo 27 : Catégorie I "léger défaut de forme" - Légère déformation - Limite admise

photo 28: Class I "slight defect in shape" - Slight deformation not caused by seed formation External and internal aspect - Limit allowed

photo 28 : Catégorie I "léger défaut de forme" - Légère déformation pas causée par le développement des graines Aspect externe et interne - Limite admise 
photo 29: Class I "slight defects in colouring"

Slight defects in colouring due to a leaf covering the cucumber during growth - Limit allowed

photo 29 : Catégorie I "légers défauts de coloration" - Légers défauts de coloration liés à une feuille couvrant la partie du concombre lors de la croissance - Limite admise

photo 30: Class I "slight skin defects" - Slight skin defect due to rubbing - Limit allowed

photo 30 : Catégorie I "légers défauts de l'épiderme" - Léger défaut de l'épiderme dû au frottement - Limite admise 
photo 31: Class I "slight skin defects" - Slight skin defect due to thrips - Limit allowed

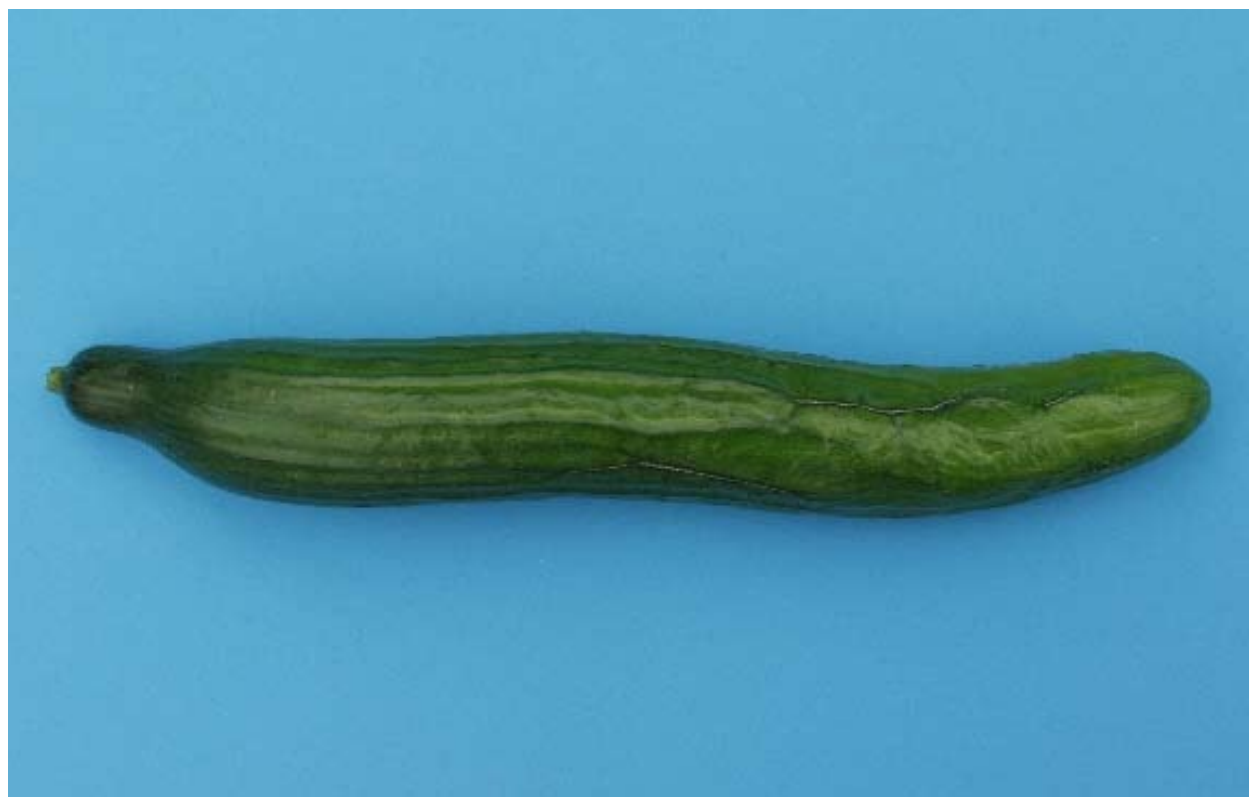

photo 31 : Catégorie I "légers défauts de l'épiderme" - Léger défaut de l'épiderme dû au thrips - Limite admise

photo 32: Class I "slight skin defects" - Slight healed cracks - due to low temperature during growth - Limit allowed

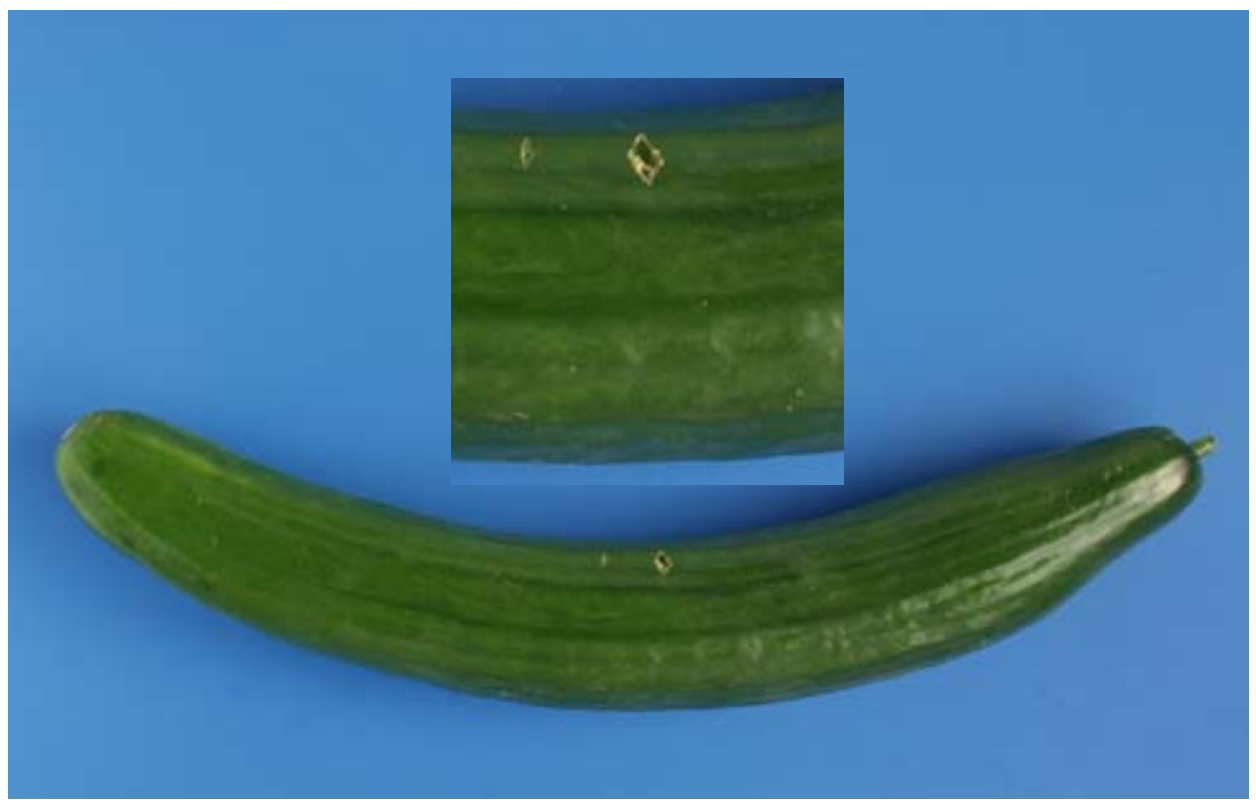

photo 32 : Catégorie I "légers défauts de l'épiderme"

Légères crevasses cicatrisées dues à de basses températures lors de la croissance - Limite admise 
photo 33: Class II "defect in shape" - Deformed cucumber - Limit allowed

photo 33 : Catégorie II "défaut de forme" - Concombre déformé - Limite admise

photo 34: Class II "defects in colouring" - Defect in colouring up to one-third of the surface - Limit allowed

photo 34 : Catégorie II "défauts de coloration" - Défaut de coloration jusqu'au tiers de la surface - Limite admise 
photo 35: Class II "skin defects" - Slight damage due to rubbing - Limit allowed

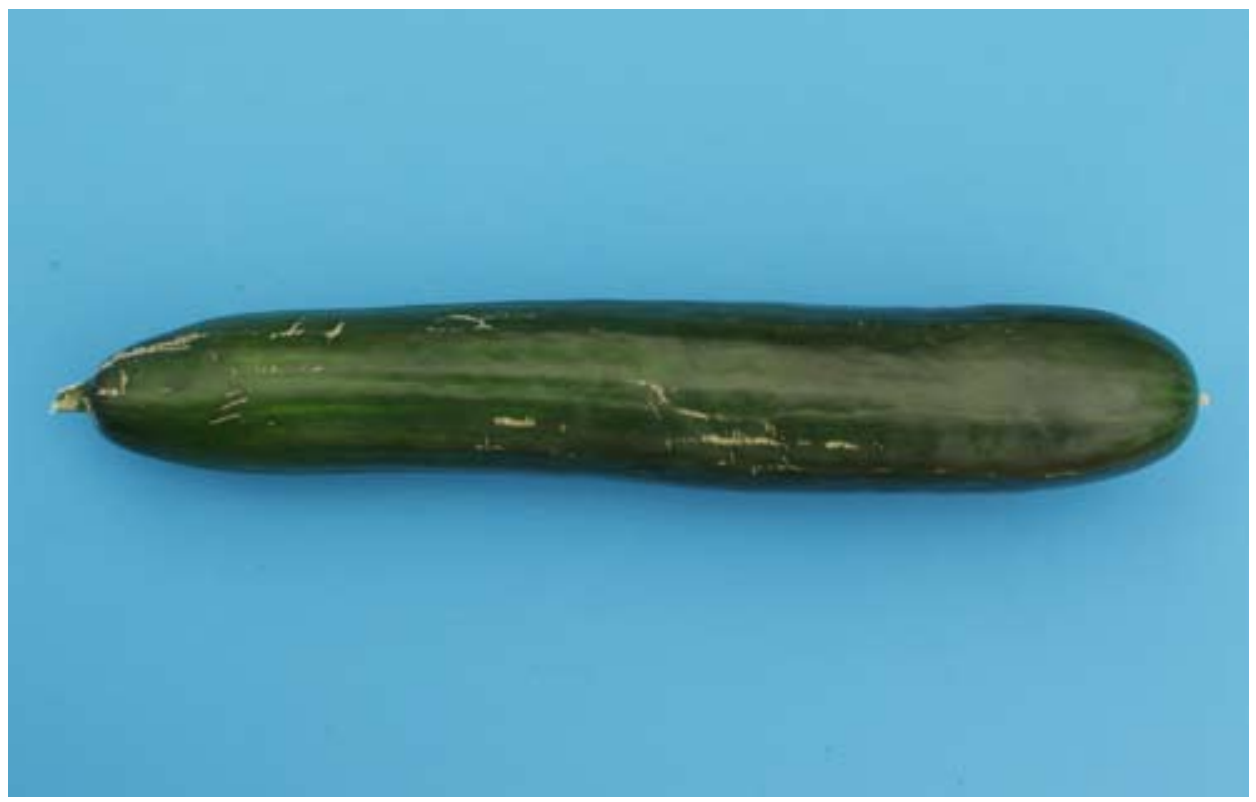

photo 35 : Catégorie II "défauts de l'épiderme" - Légères dommages causés par le frottement - Limite admise photo 36: Class II "skin defects" - Skin defects due to thrips - Limit allowed

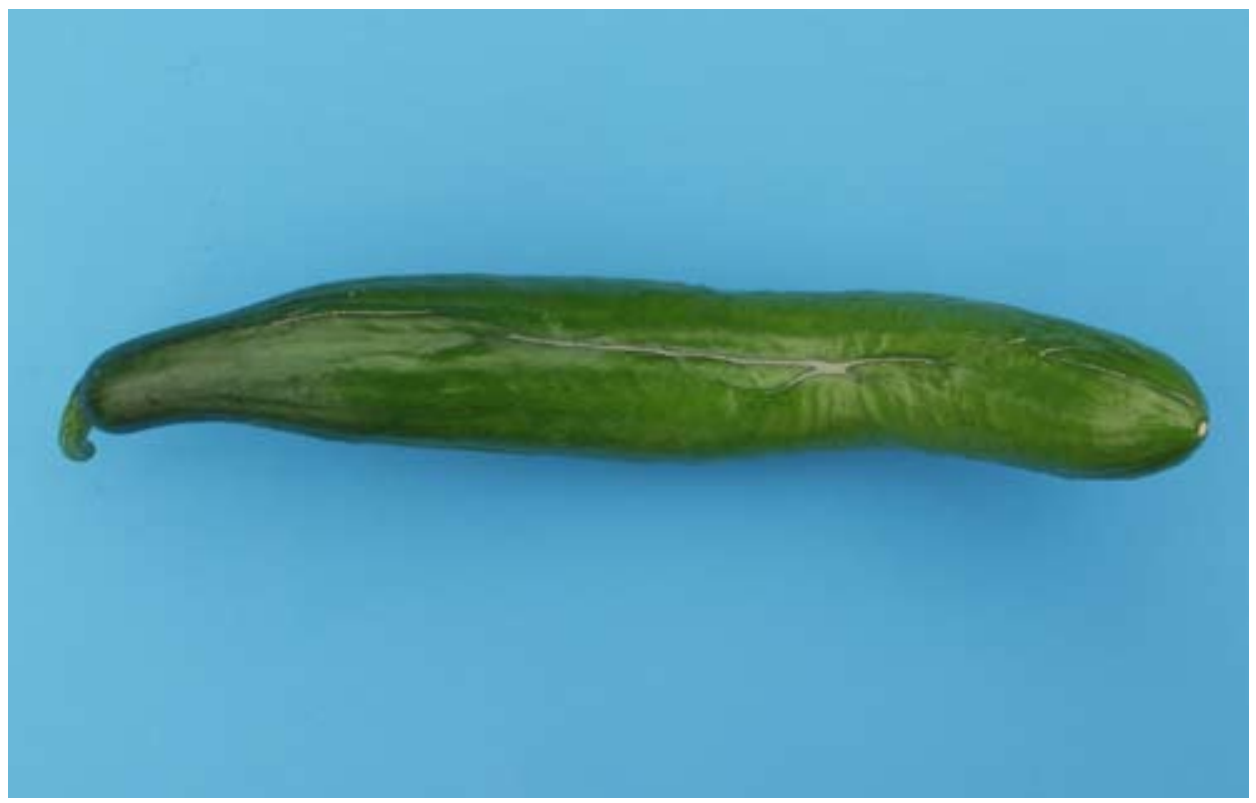

photo 36 : Catégorie II "défauts de l'épiderme" - Légères dommages causés par les thrips - Limite admise 
photo 37: Class II "skin defects" - Healed growth cracks - Limit allowed

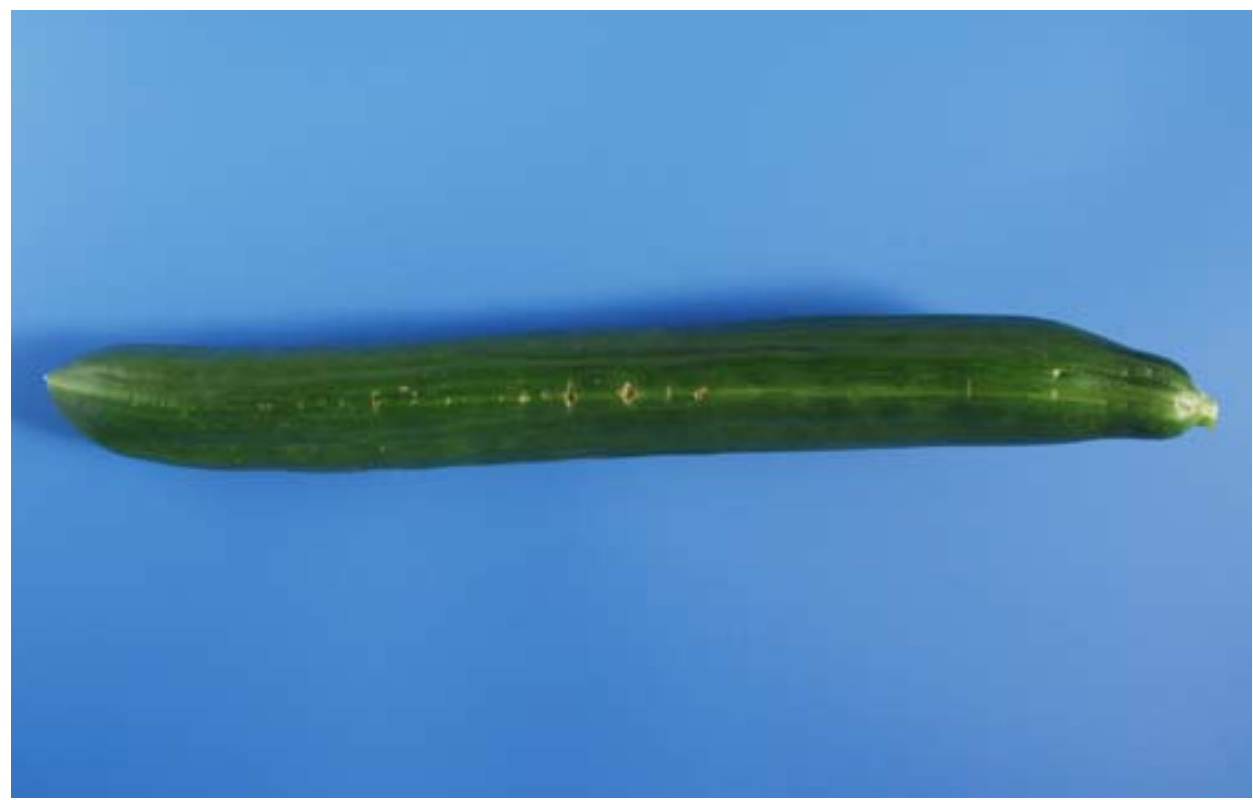

photo 37 : Catégorie II "défauts de l'épiderme" - Crevasses de croissance cicatrisées - Limite admise

photo 38: Class II "Crooked cucumber" - Crooked cucumber - Allowed, when packed separately

photo 38 : Catégorie II "concombre recourbé" - Concombre recourbé - Admis à condition de conditionnement à part 
photo 39: Class II "Crooked cucumber" - Slight defect in colouring on crooked cucumber - Limit allowed

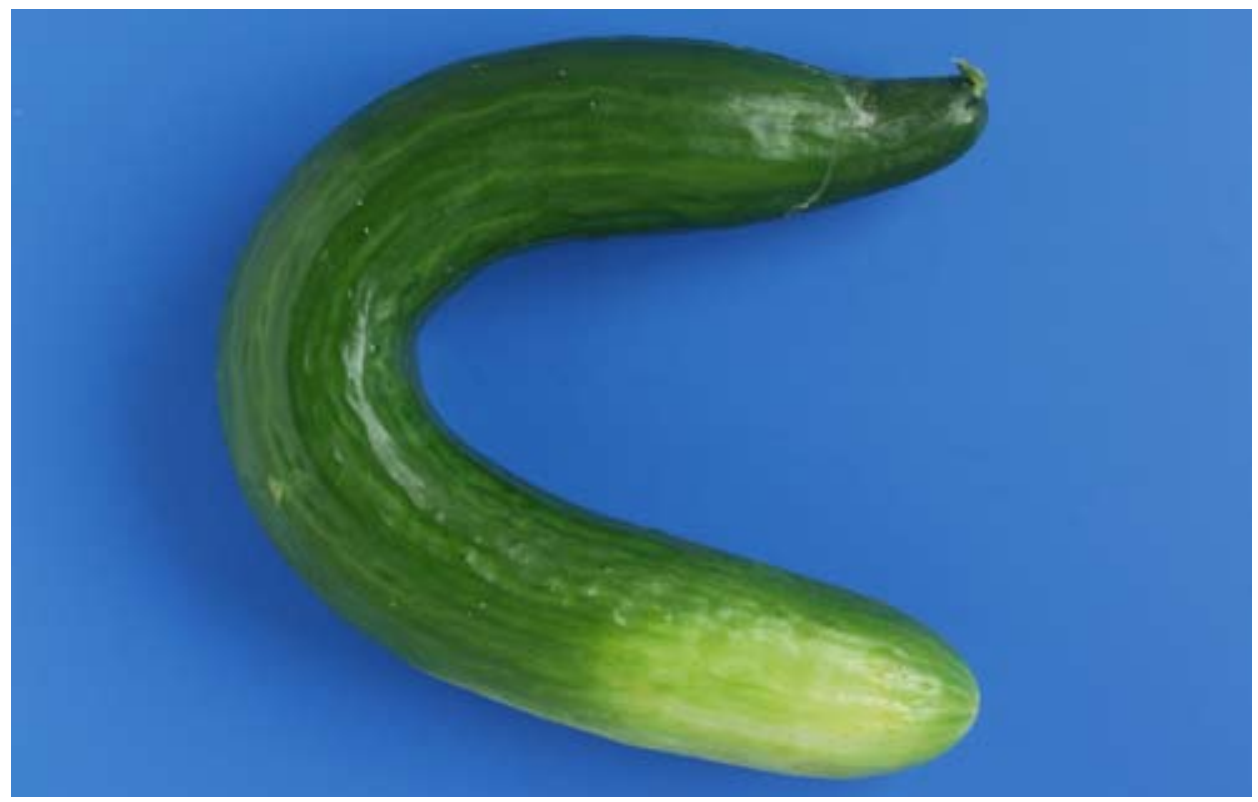

photo 39 : Catégorie II "concombre recourbé" - Léger défaut de coloration sur concombre recourbé - Limite admise

photo 40: Presentation - Very careful presentation - "Extra" Class

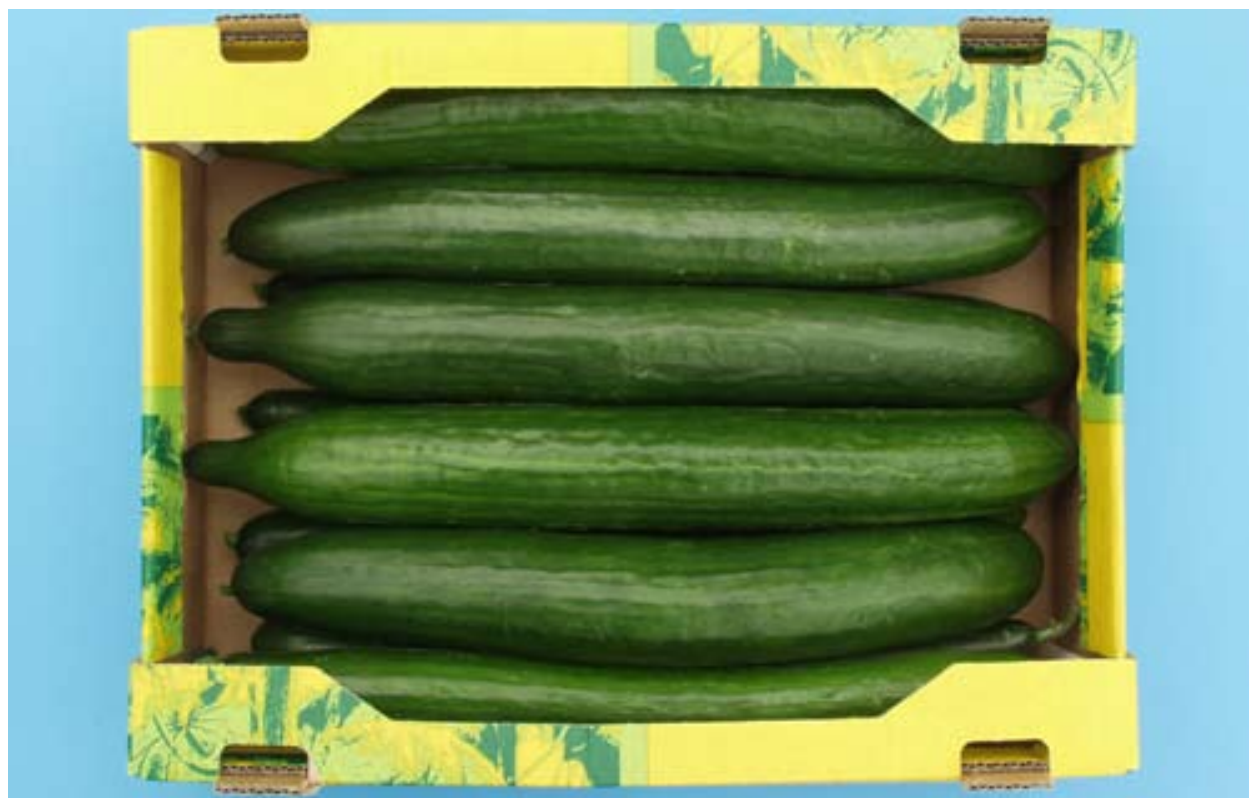

photo 40 : Présentation - Présentation très soignée - Catégorie "Extra" 
photo 41: Presentation - Careful presentation - Class I

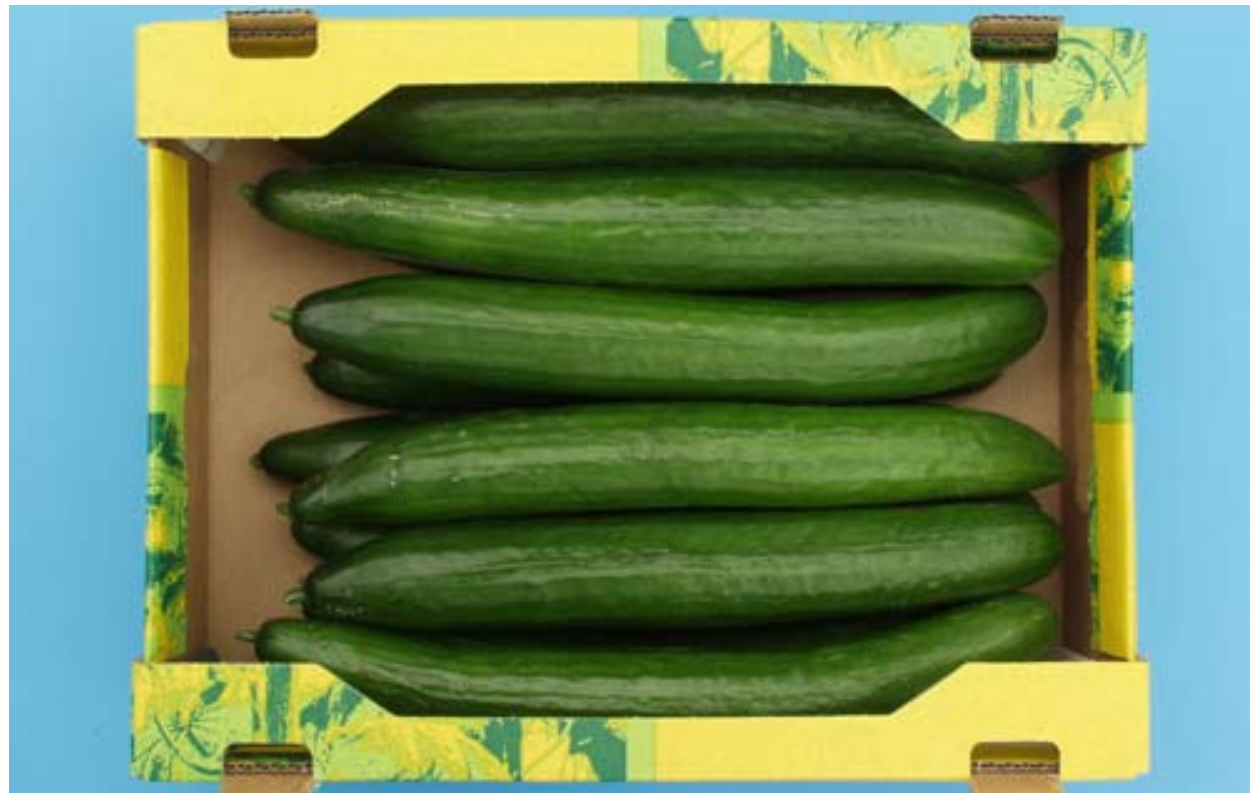

photo 41 : Présentation - Présentation soignée - Catégorie I

photo 42: Presentation - Suitable presentation - Class II

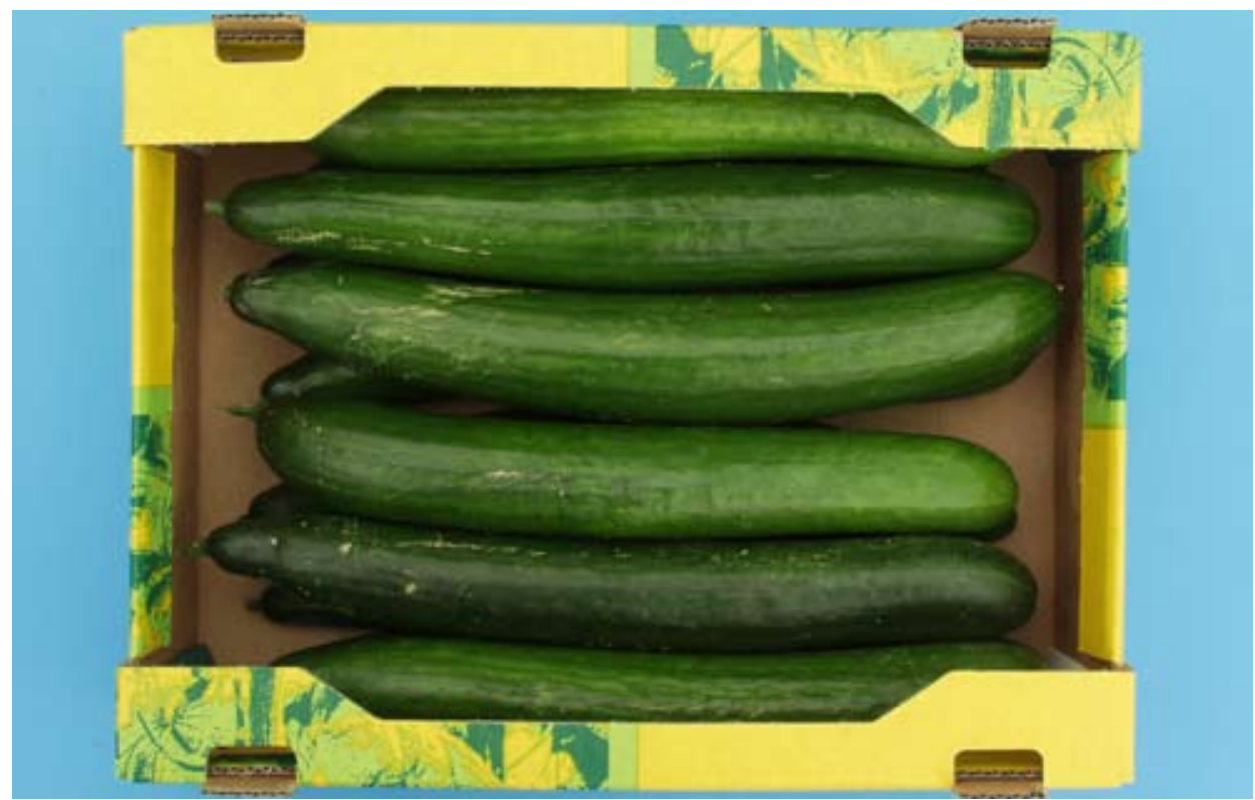

photo 42 : Présentation - Présentation convenable - Catégorie II 
photo 43: Presentation - Cucumber wrapped in film

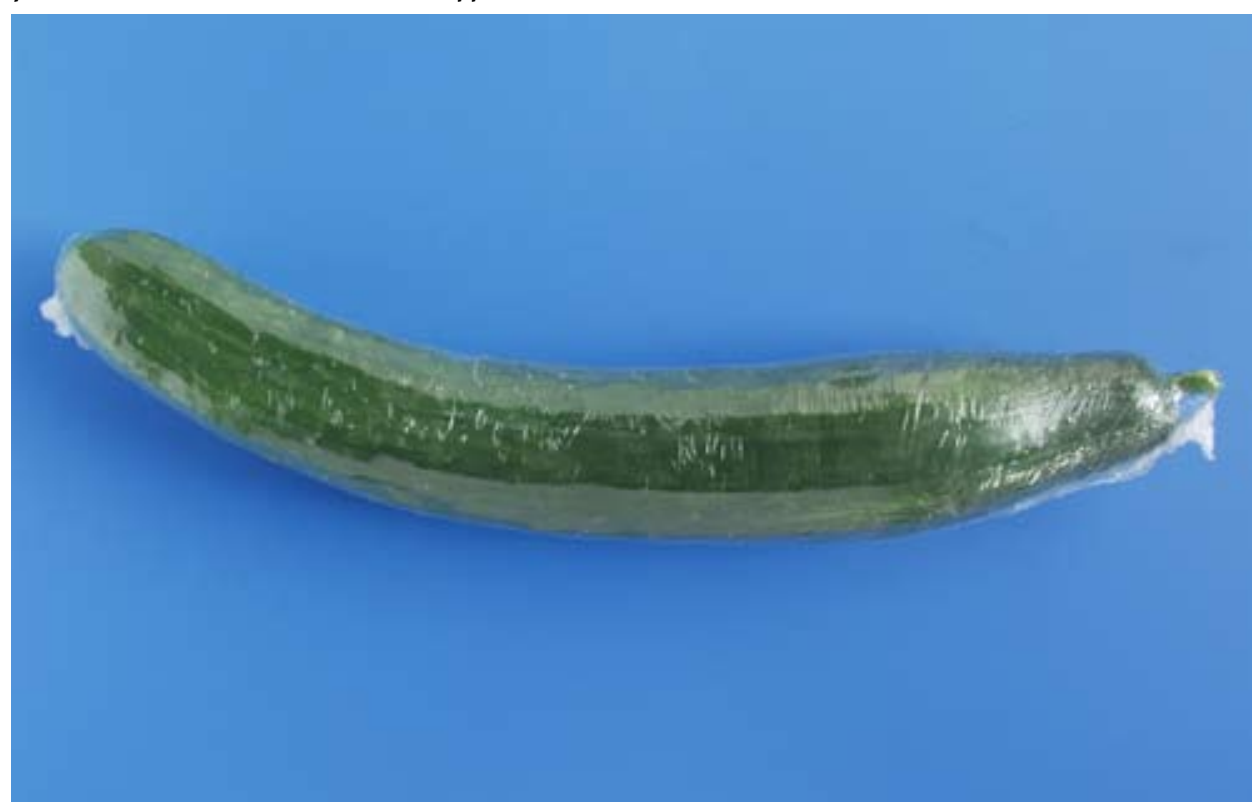

photo 44: Marking - Example of marking on a label

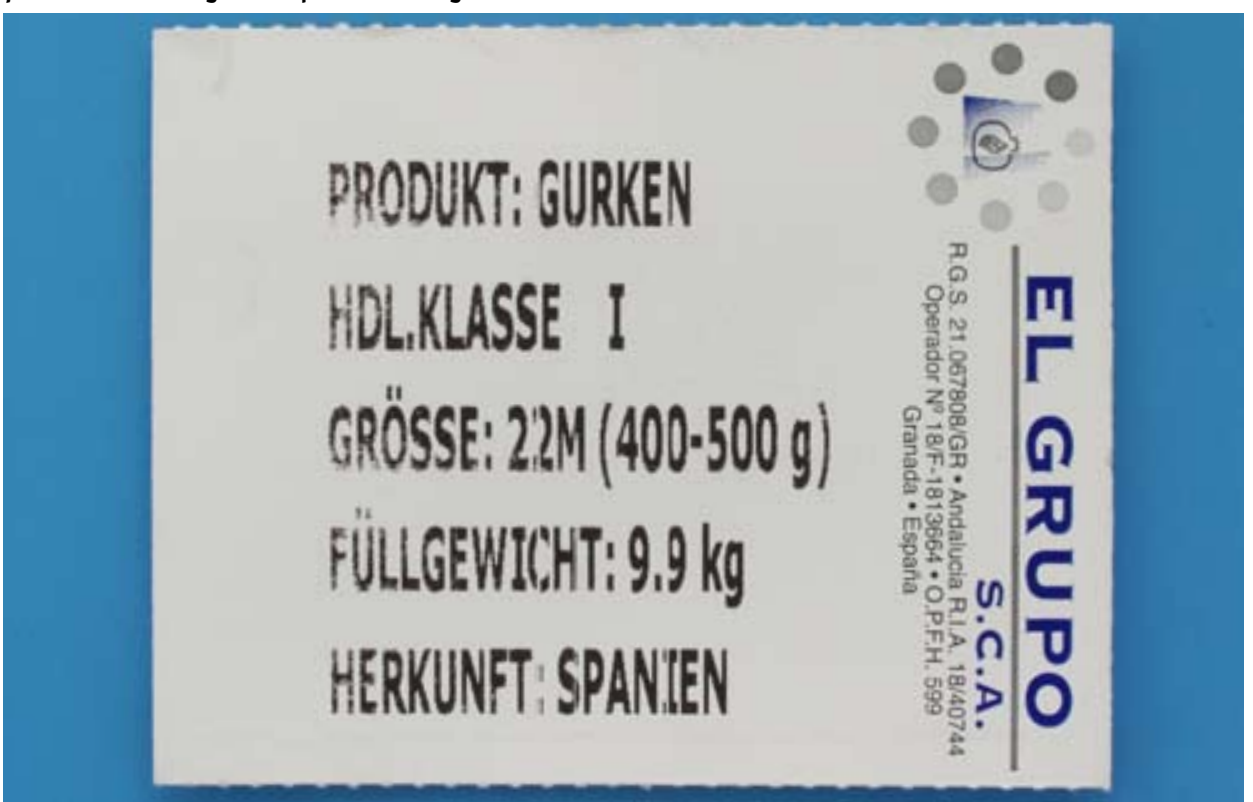

photo 44 : Marquage - Exemple de marquage sur une étiquette 
photo 45: Marking - Example of marking printed on the package

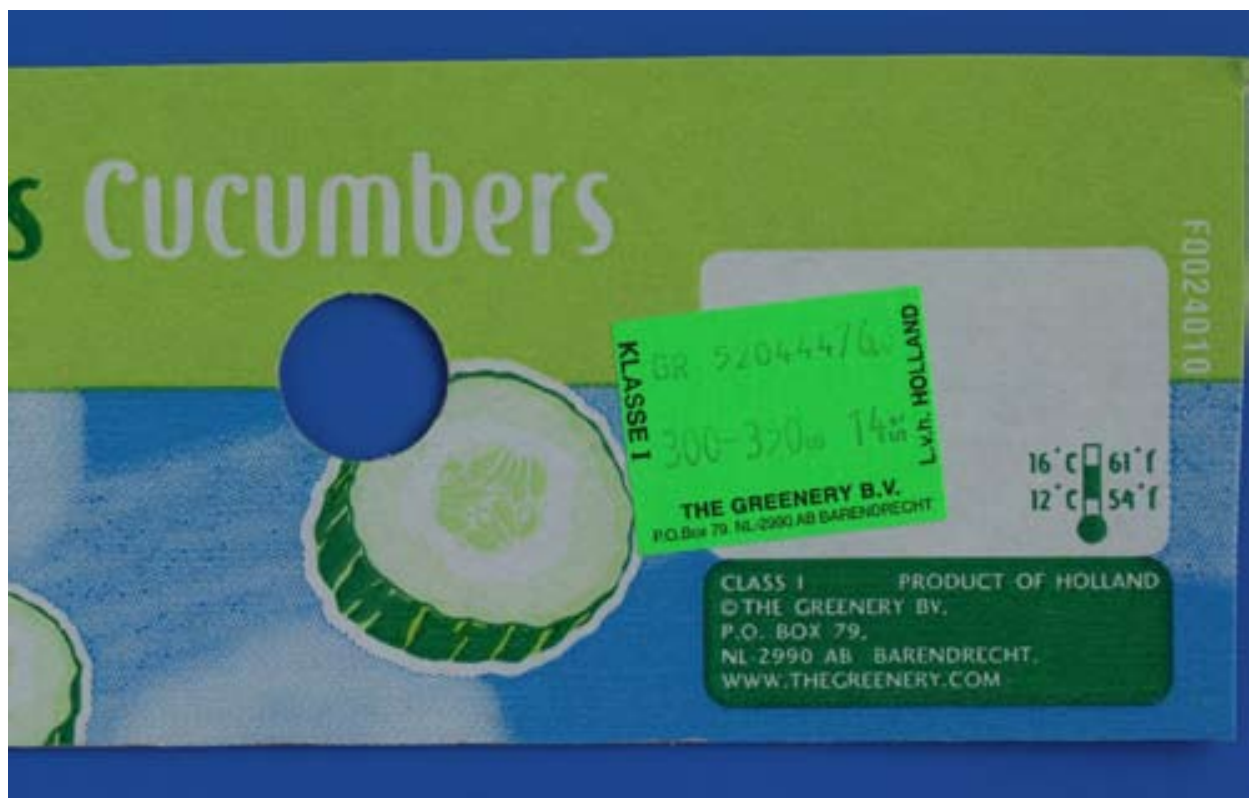

photo 45 : Marquage - Exemple de marquage imprimé sur le colis 


\begin{abstract}
LIST OF THE COUNTRIES
at present members of the OECD "Scheme"

for the application of international standards for fruit and vegetables*
\end{abstract}

\author{
LISTE DES PAYS \\ actuellement adhérents au "Régime" de l'OCDE \\ pour l'application de normes internationales aux fruits et légumes*
}

Member countries of the OECD / Pays membres de l'OCDE

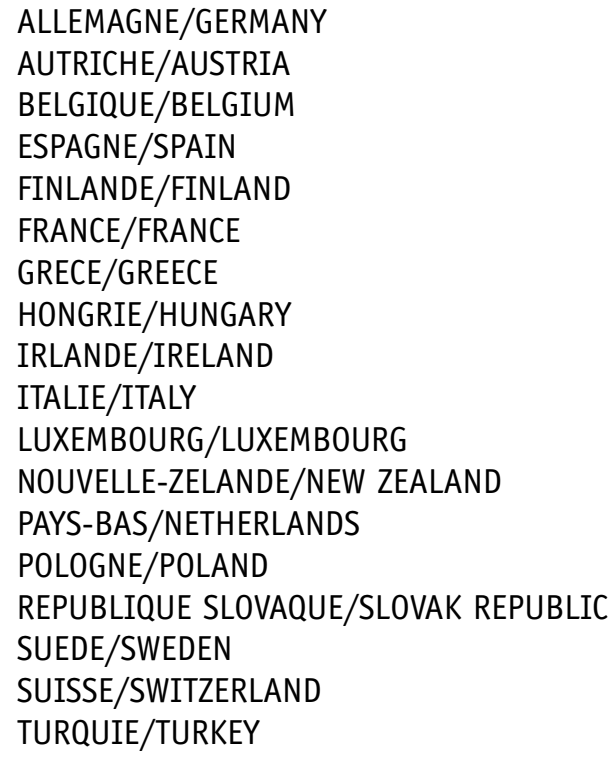

Non-OECD countries / Pays non membres de l'OCDE

AFRIQUE DU SUD/SOUTH AFRICA

BULGARIE/BULGARIA

ISRAEL/ISRAEL

MAROC/MOROCCO

ROUMANIE/ROMANIA

* $\quad$ On January 1, $2008 /$ À la date du $1^{\text {er janvier }} 2008$. 


\section{ALSO AVAILABLE \\ in the series \\ INTERNATIONAL STANDARDISATION OF FRUIT AND VEGETABLES}

The OECD Scheme for the Application of International Standards for Fruit and Vegetables (1983)

(51 1983011 P1) ISBN 92-64-12420-9 €9.00 US\$ $12.00 \quad £ 4.00$

Explanatory brochures of the standards

International Standardisation of Fruit and Vegetables. Kiwis (1992)*

(51 1992033 P1) ISBN 92-64-03697-0 €31.00 US\$39.00 £19.00

International Standardisation of Fruit and Vegetables. Mangoes (1993)*

(51 1993033 P1) ISBN 92-64-03893-0 €31.00 US\$39.00 £24.00

International Standardisation of Fruit and Vegetables. Witloof Chicories (1994)* (51 1994033 P1) ISBN 92-64-04117-6 €21.00 US\$27.00 116.00

International Standardisation of Fruit and Vegetables. Apricots (1994)*

(51 1994073 P1) ISBN 92-64-04119-2 €20.00 US\$26.00 £15.00

International Standardisation of Fruit and Vegetables. Carrots (2000)*

(51 2000013 P1) ISBN-92-64-05890-7 €22.00 US\$28.00 114.00

International Standardisation of Fruit and Vegetables. Broccoli (2000)*

(51 2000133 P1) ISBN 92-64-08538-6 €24.00 US\$31.00 £14.00

International Standardisation of Fruit and Vegetables. Asparagus (2000)*

(51 2000153 P1) ISBN 92-64-08564-5 €24.00 US\$31.00 £14.00

International Standardisation of Fruit and Vegetables. Lettuces, Curled-leaved Endives and Broad-leaved (Batavian) Endives (2002)*

(51 2002023 P1) ISBN 92-64-09711-2 €24.00 US\$31.00 £14.00

International Standardisation of Fruit and Vegetables. Plums (2002)*

(51 2002033 P1) ISBN 92-64-09-712-0 €24.00 US\$31.00 £14.00

International Standardisation of Fruit and Vegetables. Tomatoes (2002)*

(51 2002043 P1) ISBN 92-64-09-713-9 €24.00 US\$31.00 £14.00

International Standardisation of Fruit and Vegetables. Avocados (2004)*

(51 2004023 P1) ISBN 92-64-09-790 €25.00 US\$28.00 £18.00

International Standardisation of Fruit and Vegetables. Beans (2005)*

$(512005143$ P1) ISBN 92-64-01327X $€ 24.00 \quad$ US $\$ 29.00 \quad £ 16.00$ 


\section{ALSO AVAILABLE (continued)}

International Standardisation of Fruit and Vegetables. Cultivated Mushrooms (2005)* $\begin{array}{lllll}512005133 \text { P1) ISBN 92-64-01324-5 } € 24.00 & \text { US } \$ 29.00 & £ 16.00\end{array}$

International Standardisation of Fruit and Vegetables. Strawberries (2005)* $\begin{array}{lllll}(512005123 \text { P1) ISBN 92-64-01322-9 } € 24.00 \quad \text { US } \$ 29.00 & £ 16.00\end{array}$

International Standardisation of Fruit and Vegetables. Commercial types of Melons (2006)* (51 200602 3P) ISBN 92-64-02254-6 €24.00 US\$29.00 £16.00

International Standardisation of Fruit and Vegetables. Table Grapes (2007)* $(512006123$ P1) ISBN 92-64-03129-4 $€ 24.00 \quad$ US $\$ 32.00 \quad £ 17.00$

* Publications also available as electronic books

Colour gauges

International Standardisation of Fruit and Vegetables. Colour Gauge for Use by the Trade in Gauging the Skin Colouring of Apples (2000)

(51 2000063 P1) ISBN 92-64-05910-5 €30.00 US\$38.00 £16.00

International Standardisation of Fruit and Vegetables. Colour Gauge for Use by the Trade in Gauging the Skin Colouring of Tomatoes (1992)

(51 1992053 P1) ISBN 88-51-92053-0 €30.00 US\$38.00 £19.00

International Standardisation of Fruit and Vegetables. Colour Gauge for Use by the Trade in Gauging the Colour of Cauliflowers (2000)

(51 2000053 P1) ISBN 92-64-05894-X $€ 30.00 \quad$ US $\$ 38.00 \quad £ 16.00$

Prices charged at the OECD Bookshop.

THE OECD CATALOGUE OF PUBLICATIONS will be sent free of charge on request addressed either to OECD Publications Service, or to the OECD Distributor in your country. 


\section{EGALEMENT DISPONIBLES \\ dans la série \\ NORMALISATION INTERNATIONALE DES FRUITS ET LÉGUMES}

Le Régime de l'OCDE pour l'application de la normalisation internationale aux fruits et légumes (1983)

(51 1983011 P1) ISBN 92-64-12420-9 €9.00 US\$12.00

Brochures interprétatives des normes

Normalisation internationale des fruits et légumes. Kiwis (1992)*

(51 1992033 P1) ISBN 92-64-03697-0 €31.00 US $\$ 39.00$

$£ 19.00$

Normalisation internationale des fruits et légumes. Mangues (1993)*

(51 1993033 P1) ISBN 92-64-03893-0 €31.00 US\$39.00 £24.00

Normalisation internationale des fruits et légumes. Chicorées Witloof (1994)* (51 1994033 P1) ISBN 92-64-04117-6 €21.00 US\$27.00 £16.00

Normalisation internationale des fruits et légumes. Abricots (1994)* $\begin{array}{lllll}(51 & 1994073 \text { P1) ISBN 92-64-04119-2 } € 20.00 \quad \text { US } \$ 26.00 \quad £ 15.00\end{array}$

Normalisation internationale des fruits et légumes. Carottes (2000)* $\begin{array}{lllll}(512000 & 013 \text { P1) } & \text { ISBN 92-64-05890-7 } € 22.00 & \text { US } \$ 28.00 & £ 14.00\end{array}$

Normalisation internationale des fruits et légumes. Brocolis (2000)* $\begin{array}{lllll}(51200013 & 3 \text { P1) } & \text { ISBN 92-64-08538-6 } € 24.00 & \text { US } \$ 31.00 & £ 14.00\end{array}$

Normalisation internationale des fruits et légumes. Asperges (2000)*

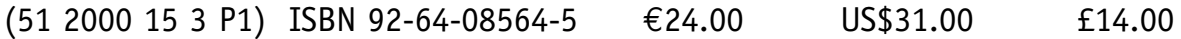

Normalisation internationale des fruits et légumes. Laitues, chicorées frisées et scaroles (2002)*

(51 2002023 P1) ISBN 92-64-09711-2 €24.00 US\$31.00 £14.00

Normalisation internationale des fruits et légumes. Prunes (2002)*

$\begin{array}{lllll}(512002033 \text { P1) ISBN 92-64-09712-0 } € 24.00 \quad \text { US } \$ 31.00 & £ 14.00\end{array}$

Normalisation internationale des fruits et légumes. Tomates (2002)*

$\begin{array}{lllll}(512002043 \text { P1) ISBN 92-64-09713-9 } € 24.00 \quad \text { US } \$ 31.00 & £ 14.00\end{array}$

Normalisation internationale des fruits et légumes. Avocats (2004)*

$\begin{array}{lllll}(512004023 \text { P1) ISBN 92-64-01979-0 } € 25.00 \quad \text { US } \$ 28.00 & £ 18.00\end{array}$

Normalisation internationale des fruits et légumes. Haricots (2005)*

$\begin{array}{lllll}(512005143 \text { P1) } & \text { ISBN 92-64-01327-X } € 24.00 \quad \text { US } \$ 29.00 \quad £ 16.00\end{array}$ 


\section{ÉGALEMENT DISPONIBLES (suite)}

Normalisation internationale des fruits et légumes. Champignons de couche (2005)* (51 2005133 P1) ISBN 92-64-01324-5 €24.00 US\$29.00 £16.00

Normalisation internationale des fruits et légumes. Fraises (2005)*

$\begin{array}{lllll}(512005123 \text { P1) ISBN 92-64-01322-9 } € 24.00 \quad \text { US } \$ 29.00 & 116.00\end{array}$

Normalisation internationale des fruits et légumes. Melons (2006)*

(51 2006023 P) ISBN 92-64-02254-6 €24.00 US\$29.00 £16.00

Normalisation internationale des fruits et légumes. Raisins de table (2007)*

(51 2006123 P1) ISBN 92-64-03129-4 €24.00 US\$32.00 £17.00

* Publications également disponibles sous forme électronique

Échelles colorimétriques

Normalisation internationale des fruits et légumes. Table colorimétrique à l'usage des milieux commerciaux concernant la coloration de l'épiderme des pommes (2000) $\begin{array}{lllll}(512000063 \text { P1) } & \text { ISBN 92-64-05910-5 } € 30.00 & \text { US } \$ 38.0 & £ 16.00\end{array}$

Normalisation internationale des fruits et légumes. Table colorimétrique à l'usage des milieux commerciaux concernant la coloration de l'épiderme des tomates (1992) $\left.\begin{array}{lllll}(51 & 199205 & 3 & \text { P1 }\end{array}\right)$ ISBN 88-51-92053-0 $€ 30.00 \quad$ US $\$ 38.00 \quad £ 19.00$

Normalisation internationale des fruits et légumes. Table colorimétrique à l'usage des milieux commerciaux concernant la coloration des choux-fleurs (2000) $(512000053$ P1) ISBN 92-64-05894-X $€ 30.00 \quad$ US $\$ 38.00 \quad £ 16.00$

Prix de vente au public dans la librairie du siège de l'OCDE. LE CATALOGUE DES PUBLICATIONS de l'OCDE sera envoyé gratuitement sur demande adressée soit à l'OCDE, Service des Publications, soit au distributeur des publications de l'OCDE de votre pays. 
OECD PUBLICATIONS, 2, rue André-Pascal, 75775 PARIS CEDEX 16 PRINTED IN FRANCE

(51 2008083 P) ISBN 978-92-64-04524-8 


\section{International Standards for Fruit and Vegetables}

\section{CUCUMBERS}

This brochure is published within the framework of the activities of the Scheme for the Application of International Standards for Fruit and Vegetables set up by OECD in 1962. It comprises comments and illustrations to facilitate the common interpretation of standards in force and is therefore a valuable tool for both the Inspection Authorities and professional bodies responsible for the application of standards or interested in the international trade in these products.

\section{Normes internationales pour les fruits et légumes}

\section{CONCOMBRES}

Cette brochure est publiée dans le cadre des activités du Régime pour l'application de normes internationales aux fruits et légumes, créé en 1962 par l'OCDE. Elle fournit des commentaires et des illustrations en vue de faciliter l'interprétation commune des normes en vigueur et constitue donc un outil précieux tant pour les services de contrôle que pour les milieux professionnels responsables de l'application des normes ou s'intéressant au commerce international de ces produits.

The full text of this book is available on line via this link: www.sourceoecd.org/agriculture/9789264045248

Those with access to all OECD books on line should use this link: www.sourceoecd.org/9789264045248

SourceOECD is the OECD online library of books, periodicals and statistical databases. For more information about this award-winning service and free trials ask your librarian, or write to us at SourceOECD@oecd.org.

Le texte complet de cet ouvrage est disponible en ligne à l'adresse suivante : www.sourceoecd.org/agriculture/9789264045248

Les utilisateurs ayant accès à tous les ouvrages en ligne de l'OCDE peuvent également y accéder via : www.sourceoecd.org/9789264045248

SourceOCDE est une bibliothèque en ligne qui a reçu plusieurs récompenses. Elle contient les livres, périodiques et bases de données statistiques de l'OCDE. Pour plus d'informations sur ce service ou pour obtenir un accès temporaire gratuit, veuillez contacter votre bibliothécaire ou SourceOECD@oecd.org. 